\title{
Kadınların Özel Hallerinde Kur'ân Okuması ve Kur'ân'a Dokunması İle İlgili Rivâyetlerin Tahlili ve Değerlendirilmesi
}

Şule Soyal Şenol*

\begin{abstract}
$\ddot{O} z$
Günümüz dünyasında kadın ve kadınlarla ilgili konular, gündemde kalmaya devam etmektedir. Son dönemlerde bazı zaruretler ve birtakım çevrelerin marjinal düşünceleri sebebiyle yeni tartışmalar ortaya çıkmıştır. İslam'ın ilk asırlarından itibaren bu güne kadar kadının özel hallerinde ibadetlerinin nasıl olması gerektiği hususu tartışılmıştır. "Kadınların özel hallerinde Kur'ân okuması ve Kur'ân'a dokunması ile ilgili rivâyetlerin tahlili ve değerlendirilmesi" adlı çalışmamız "Kadınların özel hallerinde Kur'ân okuması ile ilgili rivâyetlerin tahlili ve değerlendirilmesi" ve "Kadınların özel hallerinde Mushaf'a dokunmast ile ilgili rivâyetin tahlili ve değerlendirilmesi" şeklinde iki alt başlıktan oluşmaktadır. Kadınların hayızlı iken Kur'an okuyamayacaklarına dair Kur'an'da açık bir nassın bulunmaması sebebiyle İslam bilginleri, hayızlı kadınların Kur'an okumalarn konusunda farklı görüşler ortaya koymuşlardır. Bir grup "hayızlı kadının Kuran'a dokunması haramdır" derken, diğer bir grup "caizdir" demiştir. Buna karşılık "dokunmak haramdır ama bakabilir, dokunmadan okuyabilir" şeklinde fetvalar verilmiştir. Bu noktadan yola çıkarak ilgili fetvalara delil olarak gösterilen rivayetler derlenmiş ve senet kriterleri içerisinde incelenmiştir. Araştırma neticesinde elde edilen veriler, sonuç bölümde belirtilmiştir.
\end{abstract}

Anahtar Kelimeler: Kadınların özel halleri, Özel hallerde ibadet, Hadis tahrici, Hadis tenkidi

\section{The Analysis and Assessment of Hadith Narrations about Reciting and Touching the Quran During Women's Special Circumstances}

\section{Abstract}

In today's world, topics focusing on women and issues that are specific to women's special circumstances (menses, post-natal etc) remain on the agenda. Recently, as a result of some developments and some groups' marginal thoughts, new discussions have emerged. Throughout Islam's history, the question of how menstrual cycle and other experiences specific to women should affect their religious duties has always been the topic of discussion. Our study titled "The analysis and assessment of Hadith narrations about reciting and touching the Quran during women's special circumstances (menses, post natal bleeding, etc..)" is comprised of two separate headings; "The analysis and assessment of Hadith narrations concerning women's reciting the Quran during their special circumstances" and "The analysis and assessment of Hadith narrations concerning women's touching the Quran during special circumstances". Since there is no specific ruling mentioned in the Quran whether women can recite Quran during menstruation, various opinions were put forward by Islamic scholars in relation to reciting the Quran during menstruation. While one group of scholars state that "women are forbidden to touch the Quran during menstruation", another group argues that it is 
"permissible". In contrast, "they are forbidden to touch but are permitted to look" is another variation of argument that was put forward by some other scholars in the form of fatwas. From this perspective all Hadith narrations that served as evidence for given three form of fatwas were analysed and examined. The data obtained from this study are shared in the Results section.

Keywords: Menstruation, Special circumstances in worship, Citation of the hadith, Hadith criticism.

\section{Gíriş}

Kur'an-1 Kerim'de, kadınların hayızlı iken ibadetlerinin nasıl olması gerektiğine dair açık bir hüküm bulunmaması sebebiyle, kadınların özel hallerinde ibadet hayatının nasıl olması gerektiği belirlenirken, rivayetler esas alınmıştır. Kur'an'da açık bir nas bulunmamakla beraber âlimler, zayıf hadislerle amel edilmesi hususunda farklı yaklaşımlarda bulunmuşlardır. Bunun neticesinde Kur'an'a dokunma ve onu okuma konularında ihtilaf edilmiştir. Bir grup âlim "hayızlı kadının Kuran'a dokunması haramdır"1 derken, diğer bir grup "caizdir" demiştir. Buna karşılık "dokunmak haramdır ama bakabilir, dokunmadan okuyabilir"2 şeklinde fetvalar da verilmiştir.

$\mathrm{Bu}$ çalışmada, kadınların özel hallerinde Kur'ân okuması ve Kur'ân'a dokunması ile ilgili rivâyetler tahlil edilerek, ortaya çıkmış olan ihtilafa çözüm noktasında ilmi bir katkıda bulunulması hedeflenmektedir.

Rivâyetlerin incelenmesinde özellikle senet incelemesine ağırlık verilecektir. Örnek hadislerin incelenmesinde, aynı manayı ifade eden rivâyetler bir araya getirilerek isnat şeması oluşturulacaktır. Hadislerin senet şemalarında, râviler Hz. Peygamber'den itibaren hadisin yer aldığı musannıfının zikrettiği son râviye kadar gösterilecektir. Eğer hadisin bir senedi varsa, bu senetteki râviler birbirlerinden ok işaretiyle ayrılarak gösterilecektir.

Daha sonra, hadisin isnat şemasındaki râvilerin güvenilirlikleri tespit edilmeye çalışılacaktır. Sahabenin adaleti göz önünde bulundurulup, bazen sadece tanıtmak amacıyla hakkında bilgi verilecektir. Râvinin güvenilirliğini tespit etmeye çalışırken kimliği, vefatı, münekkitlerin tüm görüşleri olduğu gibi aktarılacaktır. İsnat şemasında yer alan her bir râvi incelendikten sonra, hadis ile ilgili genel bir değerlendirme yapilacaktır.

$\mathrm{Bu}$ aşamalardan sonra, tartışmalı konularda metin ile ilgili konulara değinilecektir ve varsa İslam âlimlerinin görüşlerine yer verilecektir. Özel hallerde Kur'ân okumak ve Mushaf'a dokunmak şeklinde oluşturduğumuz alt başlıklarda konu ile ilgili delil olarak gösterilen tüm rivâyetler bulunacaktır. Yapılan senet tetkikinden

\footnotetext{
${ }^{1}$ Şeyh Nizam, Fetâvâ-i Hindiyye, (Beyrût: Dâru'l-Fikr, 2009), I, 93; İbn Âbidin, Muhammed Emîn b. Ömer b. Abdilazîz el-Hüseynî ed-Dımaşkī, Reddu'l-Muhtâr, (Beyrût: Dâru'l-Kütübi'l-İlmiyye, 2003), I, 476; İbn Hazm, Ebû Muhammed Alî b. Ahmed b. Saîd b. Hazm el-Endelüsî el-Kurtubî, el-Muhallâ bi'l-Âsâr, (Beyrût: Dâru'l-Kütübi'l-İlmiyye, 2010), I, 95.

2Dalgın Nihat, Gündemdeki Tartışmalı Dini Meseleler, (İstanbul: Ensar Neşriyat, 2014), s. 38.
} 
sonra hangi rivâyetlerin bu konu hakkında delil olmaya uygun olduğu konusunda görüş beyan edilecektir.

\section{A. Kadınların Özel Hallerinde Kur'ân Okuması ile İlgili Rivâyetlerin Tahlili ve Değerlendirilmesi}

Hayızlı kadının Kur'ân okuyup okuyamaması yönündeki rivâyetler üç başlık altında incelenebilinir:

a) Ali b. Ebû Tâlib Rivâyeti

b) Abdullâh b. Ömer Rivâyeti

c) Hz. Âişe Rivâyeti

\section{Ali B. Ebî Tâlib Rivâyeti}

Ebû Dâvud, Hz. Ali'den şu haberi nakletmiştir:

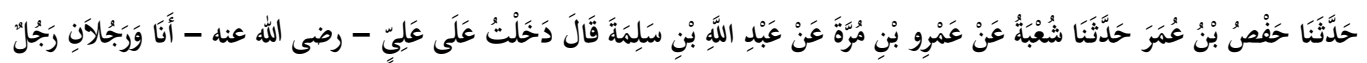

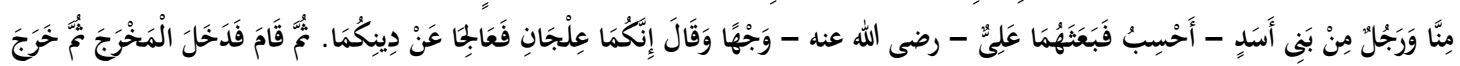

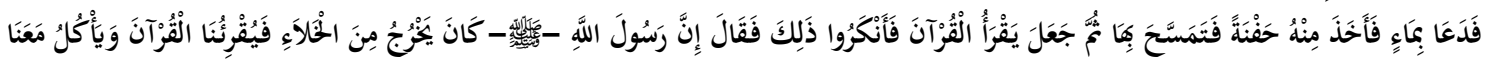

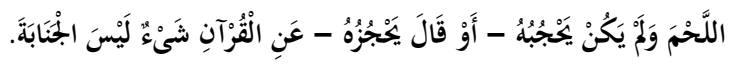

“Bize Hafs b. Ömer Şu'be'den, O da Amr b. Mürra'dan, O da Abdullâh b. Selime'den şöyle rivâyet etti: Biri bizden, diğerinin de Ben̂̂ Esed'den olduğunu zannettiğim iki kişi ile birlikte Ali (r.a.)'ın huzuruna girdim. Ali (r.a.) onları (âmil olarak veya bir başka görevle) bir tarafa gönderdi ve şöyle dedi:"Siz, ikiniz de güçlü kuvvetlisiniz. Dîniniz için çalışınız (veya dîninizi koruyunuz)." Sonra kalktı ve helâya girdi. Sonra çıtı ve su istedi. Sudan aldı ve onunla mesh etti. Sonra Kur'ân okumaya başladı. Bunu oradakiler yadırgadı. O da şöyle söyledi."Cünüplük dışında hiç bir şey, Hz. Peygamber'i Kur'ân okumaktan alıkoymazdi/menetmezdi." 3

Râvi, Hz. Ali'in (r.a.) dediğinde tereddüt etmiştir. Hangi fiil kullanılmış ise netice değişmez. Her iki fiilin mânâsı da men etmektir.

Tirmîzî, ${ }^{4}$ Nesâ̂î ${ }^{5}$ ve İbn Mâce ${ }^{6}$ de lafız farklılıklarıyla beraber Hz. Ali'den, bu haberi rivâyet etmişlerdir.

Rivâyetlerde, Hz. Ali, Abdullâh b. Selime, Amr b. Mürra ortak râviler olup şöyle bir senet şeması oluşmaktadır:

\footnotetext{
3 Ebû Dâvûd, Süleymân b. Eşâsî el-Ezdî es-Sicistânî, es-Sünen, tahkik: Muhammed Avvâme, (Beyrût: Müessesetü'r-Rayyân, 2004), Tahâret, 92; Tirmizî, Tahâret, 111; İbn Mâce, Ebû Abdillâh Muhammed b. Yezîd Mâce el-Kazvînî, Sünen-ü İbn Mâce, (Riyâd: Mektebetü'l-Maârif, tarihsiz), Tahâret, 105; Nesâî, Ebû Abdirrahmân Ahmed b. Şuayb b. Alî en-Nesâî, Sünenü'l-Kübrâ, haz. Abdullah b. A Abdu'l-Muhsin, (Beyrût: Müessesetü'r-Risâle, 2001), Tahâret, 171; Beyhakî, Ahmed b. Hüseyin, Sünenü'l-Kübrâ, (Beyrût: Dâru'l-Fikr, 2010), bâb: 98, h.n. 415.

4 “قال علي : كان رسول الله صلى الله عليه و سلم يقرئنا القرآن على كل حال مالم يكن جنبال Tirmizî, Muhammed b. Îsâ, Câmiu'l-Kebîr, tahkik: Beşşâr Avvâme, (Beyrût: Dâru'l-Ğarbi'l-İslâmî, 1996), Tahâret, 111.

" Nesâ̂î, Tahâret, 171.

6 “ و لا يحجزه عن القران شيء الا الجنابة "İbn Mâce, Tahâret, 105.
} 


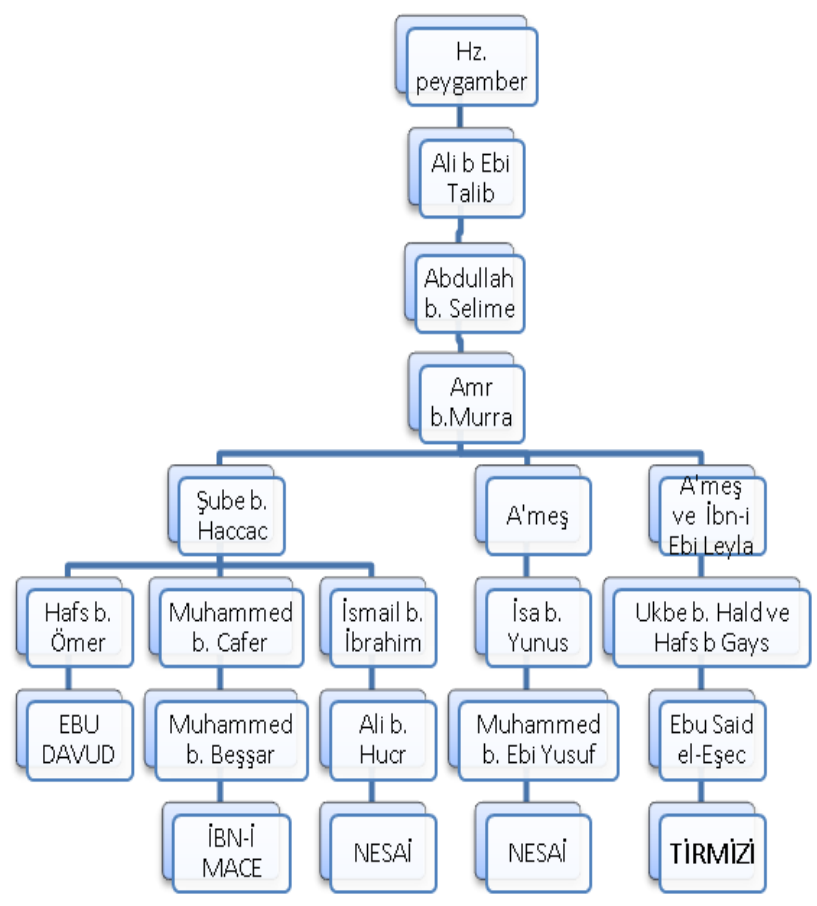

Hz. Peygamber'den sonra üç tabakada birer râvi tarafından nakledilen rivâyet ferd/gariptir. Râvilerin güvenilirlik durumları şöyledir:

Hz. Peygamber $\rightarrow$ Hz. Ali $\rightarrow$ Abdullâh b. Selime $\rightarrow$ Amr b. Mürra $\rightarrow$ Şu'be $\rightarrow$ Hafs $b$. Ömer $\rightarrow E B \hat{U}$ DÂVUD

\section{Abdullâh b. Selime (Ö. 80)}

Abdullâh b. Selime el-Hemdânî ${ }^{7}$ el-Kûfî, ${ }^{8}$ künyesi Ebû'l-Âliye'dir. Sahabeden olan Sa'd b. Ebî Vakkas, Ali b. Ebî Tâlib, Abdullâh b. Mes'ud ve Muâz b. Cebel'den rivâyet etmiştir. ${ }^{9}$ İbn Hacer "ihtilattan dolayı vehm olduğunu" söylemiştir. ${ }^{10}$ Ebû Dâvud, “Abdullah b. Selime'nin Şu'be ve Amr b. Mürra'dan yaptığı rivâyetti bilir ve inkâr ederiz, yaşlılığında dolayı hadisine tabi olunmaz" demiştir. ${ }^{11}$ Ahmed b. Hanbel, "Amr b. Mürra ve Ebû İshak' tan başkasından rivâyetini bilmiyorum" demiştir. ${ }^{12}$ İclî ve Yakup b. Şeybe "sika" olarak nitelendirmişlerdir. Buhârî, "hadisine tabi olunmaz" demiştir. ${ }^{13}$ Şu'be, "bu hadisi yaşlandıktan sonra rivâyet etmiştir" derken ilave olarak "Amr b. Mürra" bundan daha güzel hadis rivâyet etmemiştir, demiştir. ${ }^{14}$

\footnotetext{
${ }^{7}$ İbn Hacer, Ebû'l-Fazl Şihâbüddîn Ahmed b. Alî b. Muhammed, Et-Takrîbü't-Tehzîb, (Riyâd: Dâru'l-Âsîme tarihsiz), s. 248.

${ }^{8}$ Buhârî, Ebû Abdullâh Muhammed b. İsmâîl b. İbrâhîm el-Cu’fî el-Buhârî, et-Târihu'l-Kebîr, (Beyrut: Dâru'l-Kütübü'l-İlmiyye, 2008), V, 99.

${ }^{9}$ Mizzî, Ahmed b. Abdullah b. Salih, Tehzîbü'l-Kemâl, (Beyrût: Müessesetü'l-Risâle, 2010), XV, 51/ 3313.

10 İbn Hacer, Et-Takrîb, s. 248.

${ }^{11}$ Buhârî, et-Târihu'l-Kebîr, V, 99; Mizzî, Tehzîbü'l-Kemâl, XV, 52.

12 Mizzî, Tehzîbü'l-Kemâl, XV, 51.

${ }^{13}$ Mizzî, Tehzîbü'l-Kemâl, XV, 52.

${ }^{14}$ Mizzî, Tehzîbü'l-Kemâl, XV, 53.
} 


\section{Amr b. Mürra (Ö. 116)}

Amr b. Mürra b. Abdullah b. Târık b. Hâris Ebû Abdullâh el-Kûfî el-A'ma; İbrâhîm En-Nehâi, Sa'd b. Ubâde, Saîd b. Cübeyr, Said b. Müyeyyeb gibi pek çok kimseden rivâyet almış; ondan da Süfyan es-Sevrî, Süleymân el-A'meş, Şu'be b. Haccâc gibi kimseler rivâyette bulunmuştur. Buhârî yaklaşık yüz tane rivâyeti olduğunu söylemiştir. ${ }^{15}$ Ahmed b. Hanbel, "onu tezkiye etmiş", Ebû Hâtim, İshâk b. Mansûr ve Yahyâ b. Maîn'den naklen sika olduğunu söylemiştir. ${ }^{16}$ Muaz b. Muaz, Şu'be'den şöyle bir nakilde bulunmuştur: "Abdullâh b. Avn ve Amr b. Mürra dişında müdelles olmayan hiç kimseyi görmedim."17 Ukaylî ve İbnü'l-Cevz'i Duafâ kitaplarına almışlardır. ${ }^{18}$ İbn Hacer, "sika ve âbid" demiştir. ${ }^{19}$ Hicri 116 senesinde vefat etmiştir. ${ }^{20}$

\section{Şu'be b. Haccac (Ö. 83/ 160)}

Şu'be b. Haccac b. el-Verd el- Ateki Ebû Bistam el-Vasitî için İbn Hacer "sika, hafız ve mutkindir" demiştir. Abdurrahmân b. Mehdî"1 ve Sevrî, onun için "hadiste müminlerin emiri"22 Muhammed b. Sa'd O'nun için, "sika, sebt, mutkin ve hüccet" değerlendirmesini yapmıştır. ${ }^{23}$ Buhârî, Ali b. Medînî'den nakille bin kadar hadisi olduğunu söylemiştir. ${ }^{24}$

Hz. Peygamber $\rightarrow$ Hz. Ali $\rightarrow$ Abdullâh b. Selime $\rightarrow$ Amr b. Mürra $\rightarrow$ Şu'be $\rightarrow$ Muhammed b. Ca'fer $\rightarrow$ Muhammed $b$. Beşşâr $\rightarrow$ IBN MÂCE

\section{Muhammed b. Ca'fer}

Muhammed b. Ca'fer es-Semnânî el-Gumesî, Ebû Ca'fer b. Ebû'l-Hüseyn elHâfız ${ }^{25}$ için sadece İbn Hacer'in "sikadır" 26 açılamasını bulabildik.

Hz. Peygamber $\rightarrow$ Hz. Ali $\rightarrow$ Abdullâh b. Selime $\rightarrow$ Amr b. Mürra $\rightarrow$ Şu'be $\rightarrow$ İsmâîl $b$. İbrâhîm $\rightarrow$ Alî b. Hucr $\rightarrow$ NESÂ̂̃

\section{Ali b. Hucr (Ö. 144)}

Ebû'l-Hasan el-Mervezî es-Sâdî, Şüreyk, İtab b. Beşir, İsmâîl b. Ayyâş'dan rivâyet etmiştir. Kendisinden Müslim b. Haccâc en-Neysâbûrî rivâyet etmiştir. ${ }^{27}$ İbn

\footnotetext{
${ }^{15}$ Mizzî, Tehzîbü'l-Kemâl, XXII, 232-234.

${ }^{16}$ Mizzî, Tehzî̉ü'l-Kemâl, XXII, 234.

${ }^{17}$ Mizzî, Tehzîbü'l-Kemâl, XXII, 235.

${ }^{18}$ Ukaylî, Ebû Ca'fer Muhammed b. Mûsâ b. Hammâd, Kitâbü'l- Duafâi'l-Kebîr, (Beyrut: Dâru'l-Kütübü'lİlmiyye, 1984), II, 260/ 813; İbnü'l-Cevzî, Cemaluddîn Ebu'l-Ferec Abdurrahmân Alî b. Muhammed, Kitâbu'd-Duâfâi ve'l-Metrûkîn, Thk: Ebu'l-Fidâ, (Beyrût: Daru'l-Kütübü'l-İlmiyye, 1986), II, 124/ 2038.

19 İbn Hacer, Et-Takrîb, s. 363.

${ }^{20}$ Mizzî, Tehzî̉ü'l-Kemâl, XXII, 237.

${ }^{21}$ Mizzî, Tehzîbü'l-Kemâl, XII, 491.

22 İbn Hacer, Et-Takrîb, s. 208.

${ }^{23}$ Mizzî, Tehzîbü'l-Kemâl, XII, 494.

${ }^{24}$ Mizzî, Tehzîbü'l-Kemâl, XII, 489.

${ }^{25}$ Mizzî, Tehzîbü'l-Kemâl, VI, 267.

${ }_{26}$ İbn Hacer, Et-Takrîb, s. 833.

${ }^{27}$ Buhârî, et-Târihu'l-Kebîr, VI, 272.
} 
Hacer "sika ve hafız" olduğunu söylemiştir. ${ }^{28}$ Hicri 144 senesinde vefat etmiştir. ${ }^{29}$ Buhârî, Müslim, Nesâî ve Tirmîzî rivâyetlerini almıştır. ${ }^{30}$

Hz. Peygamber $\rightarrow H z$. Ali $\rightarrow$ Abdullâh b. Selime $\rightarrow$ Amr b. Mürra $\rightarrow A^{\prime}$ meş ve İbn Ebû Leylâ $\rightarrow$ Ukbe b. Hâlid ve Hafs b. Gıyâs $\rightarrow$ Ebû Saîd el-Eşec $\rightarrow$ TíRMİZî

\section{A'meş (Ö. 148)}

Süleymân b. Mihrân el-Kûfî, tâbiîn nesline mensup âlim olup hafızlığını tamamladıktan sonra öğrenimine kıraat ilmiyle başladı. Künyesi Ebû Muhammed'dir. Rivâyette bulunduğu meşhur muhaddisler arasında Saîd b. Cübeyr, Kays b. Ebû Hâzim, Ebû Vâil Şakık b. Seleme ve Şa'bî zikredilebilir. Kendisinden de Ebû Hanîfe, Şu'be, Süfyân es-Sevrî, Süfyân b. Uyeyne, Abdullâh b. Mübârek gibi hicrî II. yüzyılın meşhur âlimleri hadis rivâyet etmişlerdir. ${ }^{31}$ Hicri 148 yilında vefat etti. ${ }^{32}$ İbn Maîn "sika", Ebû Zür'a "imam", Ebû Hâtim "sika, hadisleri delil olarak kullanılabilir(hüccet)", ${ }^{33}$ Iclî “sika, sebt", ${ }^{44}$ Nesâî “sika, sebt" 35 demişlerdir.

\section{İbn Ebî Leylâ (Ö. 148)}

Muhammed b. Abdurrahman b. Ebî Leylâ el-Ensârî el- Kûfî, ${ }^{36}$ fakîh ve Kûfe'li bir kadıdır. Yahya b. Saîd "zayıf saymıştır", Ahmed b. Hanbel "hafızası kötü, muzdaribü'l-hadîs", Şu'be "hafızası ondan daha kötü kimse görmedim", Iclî " sünnet sahibi, sünnet sahibi, câizü'l-hadis", Nesâî "leyse bi kavî (kuvvetli değildir)" 37 demiştir. İbn Hacer "sadûk ama hafızasının cidden kötü" olduğunu söylemiştir. ${ }^{38}$

\section{Rivayetlerin Değerlendirilmesi}

Hz. Peygamber'den sonra üç tabakada birer râvi tarafından rivâyet edildiği için hadis ferd/gariptir. Abdullâh b. Selime ihtilatı sebebiyle cerh edilmiştir. Kendisinden sonra gelen râviler sika olsa bile Abdullâh b. Selime, ömrünün sonlarına doğru bunamıştır. Ondan hadis rivâyet edenlerin rivâyetlerine galat, 1zdırab, telkin ve ref' gibi çeşitli hadis kusurları karışmış olma ihtimali bulunmaktadır. Bu sebeple söz konusu rivâyetlerin zayıf sayılması gerekmektedir.

\footnotetext{
28 İbn Hacer, Et-Takrîb, s. 338.

${ }^{29}$ Buhârî, et-Târihu'l-Kebîr, VI, 272.

30 İbn Hacer, Et-Takrîb, s. 338.

${ }^{31}$ Ebû Hâtim er-Râzî, El-Cerh ve't-Ta'dil, IV, 139.

32 İbn Hacer, Et-Takrîb, s. 414.

${ }^{33}$ Mizzî, Tehzîbü'l-Kemâl, XII, 489.

${ }^{34}$ Iclî, Ahmed b. Abdillâh, Ma'rifetü's-Sikât, tahkik: Abdü'l-Âlim el-Bustî, (Medine: Mektebetü'd-Dâr 1985),

I, 432-434.

35 İbn Hacer, Tehzîlbü't-Tehzîb, III, 58-59.

${ }^{36}$ Ebü'l-Ulâ Muhammed Abdurrahmân b. Abdirrahîm el-Mübârekpûrî, Tuhfetu'l-Ahvezî bi Şerhi Câmi'iTirmizî, haz. Abdu'r-Rahmân Muhammed Osman, (Mısır: Dâru'l-Fikr, 1968), I, 453.

${ }_{37}$ Mizzî, Tehzîbü'l-Kemâl, XXV, 622-628/ 5406; Ukaylî, Kitâbü'l- Duafâi'l-Kebîr, IV, 98/ 1653; Nesâî, Ebû Abdirrahmân Ahmed b. Şuayb b. Alî en-Nesâî, ed-Duâfâ ve'l-Metrûkîn, Thk: Kemâl Yusuf el-Hût, (Beyrût: Müessesetü'l-Kütübü'l-Sekafiyye, 1985), 212/ 550.

38 İbn Hacer, Et-Takrîb, s. 427.
} 
Tirmîzî, bu rivâyet hakkında şöyle demiştir: "Ali b. Ebî Tâlib'in hadisi, hasen sahih $^{39}$ bir hadistir. Peygamber (s.a.v.)'in ashabından ve tabiinden pek çok kimse bu görüşte olup şöyle demektedirler: "Abdestsiz olarak Kur'ân okunur fakat Mushaf'a temiz olanlar el sürerek okumalıdır." Sûfyân es-Sevrî, Şâfiî, Ahmed ve İshâk bu görüştedir. ${ }^{40}$ İbn Hibban da bu rivâyeti kaydettikten sonra sahih bir hadis olduğunu söylemiştir. ${ }^{41}$ Yine Ebû Îsâ, hasen sahihtir demiştir. ${ }^{42}$

Öte yandan İmam Şâfiî, bu rivâyetin sübutunun kat'i olmadığını belirtmiştir. Beyhâkî, söz konusu rivâyetin sadece Kûfeli Abdullâh b. Selime kanalıyla geldiğini ve yaşlandıktan sonra rivâyet ettiğini söylemiştir. ${ }^{43}$

Ancak bu rivâyetin illetli olduğunu söyleyen âlimler de vardır. Onlar, Abdullâh b. Selime'nin yaşlandıktan sonra hıfzının bozulduğunu ve bu hadisi de yaşlılık döneminde nakletmiş olabileceğini ifade ederek, onun hadislerinin delil alınmasının doğru olmayacağını ifade etmişlerdir. ${ }^{44}$ Beyhâkî, Abdullâh b. Selime, sebebiyle bu rivâyette tevakkuf ettiğini söylemiştir. ${ }^{45}$ Hattabî, Ahmed b. Hanbel hadisi, Abdullâh b. Selime sebebiyle vehmettiğini söylemiştir. ${ }^{46}$ Ahmed b. Hanbel, Abdullâh b. Selime için Amr b. Mürra ve Ebû İshâl el-Hamedâni'den başka kimseden rivâyetini bilmiyorum demiştir. ${ }^{47}$ İbn Mâce Sünen'inin tahkikinde bu rivâyete zayıf olarak not düşülmüştür. ${ }^{48}$

Şeyhan, Abdullâh b. Selime'nin tan edilmemiş olması sebebiyle bu hadisle ihticac etmemişlerdir. ${ }^{49}$ İbn Hacer, ihtilatından önce makbul sayıldığını söylemiştir. ${ }^{50}$

Sünen-i Erbaa' ile Ahmed b. Hanbel'in Müsned'inde hadisleri bulunan ve Hz. Ali başta olmak üzere birçok sahabeden hadis nakleden Abdullâh b. Selime, muhaddislerin ekserisi tarafından muteber görülen bir râvidir. İbn Hacer, "bazı muhaddislerin onun yaşlandıktan sonra hıfzının bozulduğunu ifade ederek, hadislerine itibar etmemişlerdir" demiştir. Buhârî, onun yaşlandıktan sonra hıfzının bozulmasını gerekçe göstermek suretiyle hadislerini kitabına almamıştır. ${ }^{51}$

\footnotetext{
39 Tirmizî'nin hasen sahih tabiriyle vasıflandırdığı hadisler hakkındaki değerlendirmelerden en uygunu, böyle bir hadisin derece bakımından hasenden üstün, ama sahihten aşağı mertebede olması demektir. İbn Receb, Şerhu 'İleli't-Tirmizî, (Ürdün: Mektebetu'l-Menar, 1987), II, 609-611.

40 Tirmizî, Tahâret, 111.

${ }^{41}$ Mübârekpûrî, Tuhfetü'l-Ahvezî, I, 408.

42 Abdullah el-Hanefi, Şerhu Sünen-i İbn Mâce, III, 752.

${ }^{43}$ Mübârekpûrî, Tuhfetü'l-Ahvezi, I, 408; Azimâbâdî, Ebû Abdirrahman Şer'îf, Avnu'l-Ma'bûd Şerh-u Sünen-i Ebî Dâvîd, (Beyrût: Dâru İbn Hazm, 2005), I, 381

${ }^{44}$ Hattâbî, Ebû Süleymân Hamed b. Muhammed b. İbrâhîm el-Hattâbî el-Büstî, Meâlimü's-Sünen, haz. Muhammed Râgıb et-Tabbâh, (Halep: Matbaâtü'l-İlmiyye, 1932), I, 76.

${ }^{45}$ Azimâbâdî, Avnu'l-Mabûd, I, 382; Abdullah el-Hanefi, Şerhu Sünen-i İbn Mâce, III, 753.

${ }^{46}$ Azimâbâdî, Avnu'l-Mabud, I, 383.

47 Ahmed b. Hanbel, Kitabu'l -ílel ve Marifeti'r-Rical, haz. İsmail Cerrahoğlu, Talat Koçyiğit, (Ankara: Ankara İlahiyat Yayınları, 1963), s. 1963.

48 İbn Mâce, Sünen, I, 114.

${ }^{49}$ Abdullah el-Hanefi, Şerhu Sünen-i İbn Mâce, III, 752.

50 İbn Hacer, Et-Takrîb, s. 512.

${ }^{51}$ İbn Adiy Cürcâni, el-Kâmilü fî Duâfâi'r-Ricâl, (Lübnan: Dâru'l-Kütübi'l-İlmiyye, 2011), V, 280; Zeylâ̂, Nasbu'r-Râye, I, 258.
} 
Süfyan es-Sevrî, Şu'be b. Haccâc'in bu rivâyetin muteber olduğunu şu sözleriyle dile getirdiğini nakletmiştir: “Ben, Amr b. Mürra'nın, Abdullâh b. Selime'den rivâyet ettiği hadisler içinde bundan daha güzelini nakletmiş değilim. Bu hadis, sermayemin üçte birine denktir." 52 Fakat Şu'be, "Bu hadisi Abdullâh b. Selime yaşlandıktan sonra rivâyet etti" demiştir.53

Amr b. Murra el-Kûfî, Kütüb-ü Sitte râvilerinden olup "sika, imam ve hüccettir" denilmiştir. İbn Maîn, Ebû Hâtim, Şu'be gibi hadis nakkadları, onun "güvenilir" olduğunu söylemiştir. İmam Şu'be onun "sika ve güvenilir kimse" olduğunu beyan ederek hadislerini nakletmede özen göstermiş ve hakkında şunları söylemiştir: "Pek çok sadık râviye rastladım. Ama onlardan sadece Amr b. Murra müdellis değildir."54

Hz. Ali hadisi, Abdullâh b. Selime dışında sahih hadis râvileri tarafından nakledilmiştir. Abdullâh $b$. Selime ise, adalet ve zabt-hıfz yönünden güvenilir kimse olmakla birlikte, sadece yaşlandıktan sonraki rivâyetlerinde karışıklık bulunduğu gerekçesiyle zabt-hıfz yönünden cerh edilmektedir. Adalet yönünden sağlam olup da zabt-hıfz yönünden sika râviler derecesine ulaşamayan kimselerin hadislerine hasen denildiği bilinmektedir. Abdullâh b. Selime'nin bu rivâyeti, böyle bir kaideye göre değerlendirilse bile, söz konusu hadisin hasen mertebesinde olması gerekir. ${ }^{55}$

Sonuç olarak Şevkânî şunları söyler: “Hadisler Mushaf'a ancak tâhir olanların dokunabileceğine delalet etmektedir. Fakat tâhir kelimesi müşterek bir lafız olup mümin olmaya, büyük ve küçük abdestsizlikten arınmışlı̆ga ve beden temizliğine delalet edebilmektedir. Nitekim "Müşrikler ancak pisliktirler" ayeti tâhirden maksadın mü'min olmak olduğuna, "Eğer cünüpseniz yıkanın" ayeti abdestsizlikten arınmışlığa, yine maddî ve manevî pislikten arınmışlığa 'tâhir' denilmiş olmasına işaret etmektedir. Hukukçuların tercih ettiği görüşe göre ise müşterek bir lafız, mücmel olup, mübeyyen edilmedikçe kendisiyle amel olunmaz." 56

Hz. Ali' den gelen bu haberi destekleyen başka rivâyetler de vardır. ${ }^{57}$

\section{Hadislerden Çıkarılan Hükümler}

Cumhura göre bu hadis cünüp bir kimsenin Kur'ân okumasının caiz olmadığına delâlet etmektedir. Cumhur her ne kadar cünübün Kur'ân okuyamayacağında hem fikir ise de, bazı durumlarda aralarında görüş ayrılıkları

\footnotetext{
52 İbn Adiy, el-Kâmilü fî Duâfâ, V, 281.

${ }^{53}$ İbn Adiy, el-Kâmilü fî Duâfâ, V, 281.

54 İbn Hacer, Tehzîbu't-Tehzîb, V, 92.

55 İbn Hacer, Fethu'l-Bâri Şerhu Sahih-İ Buhârî, (Riyâd: Dâru's-Selâm, 2000), I, 233; Aynî, Ebû Muhammed (Ebü's-Senâ) Bedrüddîn Mahmûd b. Ahmed b. Mûsâ b.Ahmed el-Aynî, Umdetü'l-Kâri fi Şerhi Sahîhi'lBuhârî, (Beyrût: Dâru'l- Kitâbi'l-İlmiyye, 2005), III, 274; el-Mübârekpûrî, Tuhfetu'l-Ahvezî, I, 409.

${ }^{56}$ Şevkânî, Ebû Abdullah Muhammed b. Ali b. Muhammed el-Havlâni, Neylü'l-Evtâr min Esrâri Münteka'lAhbâr, haz. Enver el-Bâz, (Misır: Dâru'l-Vefa, 2008), I, 294.

${ }^{57}$ Bkz. Ahmed b. Hanbel, Müsned, I, 110; Dârekutni, Sünen, I, 118.
} 
vardır..$^{58}$ Şöyle ki; Şâfiîlere göre, zikir maksadıyla okunabilir. İmam Mâlik ve Ahmed b. Hanbel, "Cünübün bir âyet kadarını okumasına ruhsat verilir" demiştir. Hanefilere göre: Duâ ve senaya dâir olan âyetleri, duâ ve sena maksadıyla okumak caizdir. Süfyân-1 Sevrî, İbn-ü'l-Mübârek, Şâfiî, Ahmed ve İshak'in dâhil oldukları bu âlimlere göre cünüp ve hayız hâlindeki kadın Kur'ân' dan bir âyet dahi okuyamaz. ${ }^{59}$

Hattâbî şöyle der: “Cünübün Kur'ân okuyamayacağı hükmü, hadisten çıkarılıyor. Hayız olan kadın da okuyamaz. Çünkü onun abdestsizliği, cünübün abdestsizliğinden daha ağırdır." İmam Mâlik, cünübün bir âyet miktarını okuyabileceğini söylerken bu görüşünü, şu gerekçeye bağlamıştır: "Hayız olan kadın Kur'ân okuyabilir. Fakat cünüp okuyamaz. Hayız süresi uzayabildiği için kadın okumadığı takdirde, Kur'ân'ı unutabilir. Fakat cünüplük süresi uzun değildir, bu kişinin kendi elindedir." 60

Cünüp iken Kur'ân okumanın haram olduğunu söyleyen Cumhura göre, " zikir"den maksat, Kur'ân-1 Kerîm'in dışında olan tesbih, tehlil, tekbir ve tahmiddir. ${ }^{61}$

Hanefîler, Şâfiiler ve Hanbelîler; “Kur'ân'ı öğreten ve öğrenen dâhil hiç kimse abdestsiz olarak Kur'ân'ı elleyemez. Ancak çocuğun, âyetlerin yazılı olduğu levhaları ellemesi zaruret icâbı caizdir." derler.

Cünüp iken, bir örtü veya çubuk ile de olsa Kur'ân'a dokunmak, imamların çoğunluğuna göre haramdır. Hanefilere göre; Kur'ân'a bitişik olmayan bir kılıf, bir mahfaza, bir torba veya sandık içinde bulunan bir Mushaf'ı tutmak caizdir. Bunların haricinde haramdır. Kur'ân Kerîme cünüp iken el sürmenin haram olduğu görüşünde olan Âlimler; "Ona (Kur'ân'a) tam bir surette temizlenmiş olanlardan başkası el süremez, $(\mathrm{O})$ âlemlerin Rabbinden indirilmedir"62 âyetine dayanmışlardır. Semerkandî, cünüp ve hayızlının ayet yazmasını mekruh görür ve "çünkü yazma işi de dokunmadir" der.63

Hanefî, Şafiî ve Hanbelîlere göre, abdestsiz olan kişinin de Kur'ân-1 Kerîm'e dokunması da haramdır. Kur'ân'a bitişik olan cildi, kenarındaki beyaz kısım ve satırlarının arası için de hüküm aynıdır. Yalnız, Hanefî ve Hanbelîlere göre,

\footnotetext{
${ }^{58}$ Es-Subkî, Mahmûd Muhammed Hattâb es-Sübkî, Menhelü'l-Azbi'l-Mevrûd, haz. Emin Mahmud Hattab, (Riyâd: Mektebetü'l- İslamiyye, 1974), I, 303; Hattâbî, Meâlimü's-Sünen, I, 76; Azîmâbâdi, Avnu'l-Ma'bûd, I, 385.

59 Yavuz, Yunus Vehbi, "Hayız", TDV İslâm Ansiklopedisi (DİA), XVII, 52; İbn Hacer, Fethu'l-Bâri, II, 48; Subkî, Menhelü'l- Azbi'l-Mevrûd, I, 303.

${ }^{60}$ el-Mâverdi, Ebü'l-Hasen Alî b. Muhammed b. Habîb el-Basrî el-Mâverdî, el-Hâvi'l-Kebir fî̀ Fıkhi Mezhebi'ş-Şafî̀, (Beyrut: Daru'l-Kütübi'l-İmiyye, 1994), I, 147; İbn Kudâme, Ebû Muhammed Muvaffakuddîn Abdullah b. Ahmed b. Muhammed b. Kudâme el-Cemmâîlî el-Makdisî, el-Muğnnî, (Riyad: Mektebetü'r-Riyâdi'l-Hadîse, 1971), I, 144; Abdullah el-Hanefi, Şerhu Sünen-i İbn Mâce, III, 763; Hattâbî, Meâlimü's-Sünen, I, 76; Mübârekpûri, Tuhfetül-Ahvezî, I, 408; Kandehlevî, Muhammed Zekeriyyâ, Kevkebü'd-Düreri alâ Câmi'itTirmîẑ̂, (Hindistan: Nedvetü'l-Ulemâ, 1975), I, 212; Es-Subkî, Menhelü'l- Azbi'l-Mevrûd, I, 303.

${ }^{61}$ Nevevî, Ebû Zekeriyyâ Yahyâ b. Şeref b. Mürî en-Nevevî, el-Minhâc fî şerhi Śâhîhi Müslim b. Haccâc, (Misır: Matbaâtü'l-Misriyye, 1929), IV, 68; Es-Subkî, Menhelü'l-Azbi'l-Mevrûd, I, 73.

62 Vâkı 56/79.

${ }^{63}$ Abdullâh el-Hanefî, Şerhu Sünen-i İbn Mâce, III, 763; Es-Subkî, Menhelü'l-Azbi'l-Mevrûd, I, 304.
} 
abdestsizin, Kur'ân-1 Kerîm'e bitişik olmayan kılıfı ile veya elbisesinin yeni ile dokunması caizdir. ${ }^{64}$

Cünüp veya hayız olan kimse, yanması, suya batması, kâfirin eline geçmesi veya necasete düşmesinden korktuğu takdirde, Mushaf'ı eline alabilir. Eğer eline almaz ve kurtarma imkânı varken yanmasına, suya batmasına veya kâfirin eline geçmesine göz yumarsa günahkâr olur. ${ }^{65}$

Ebû Muhammed el-Fârisî Hz. Ali rivâyeti ile ilgili şu açıklamaları yapmıştır: “Bu hadis, Kur'ân kıratının, secdenin, Mushaf'a dokunmanın, Allah'ı zikretmenin abdestli-abdestsiz, cünüplü ve hayızlı olan herkese caiz olduğuna işaret eder. Eğer bir takım yasakları ortaya koyduğu söylenirse, bunu söyleyenin delil getirmesi gerekir. Ebû Rebia, İbn Müseyyeb, İbn Abbâs, Saîd b. Cübeyr, Dâvud gibi arkadaşlarımızda bunun böyle olduğunu söylemiştir." 66

İbn Münzîr, Taberî, İbn Abbâs, Dâvûd ez-Zâhirî, İkrime ve İbn Müseyyeb göre, cünüp iken Kur'ân okumak caizdir, derler. Bunlar Hz. Âişe' den rivâyet edilen, "Rasûlullah (s.a.v.) her halinde Allah'ı zikrederdi" hadisine dayanmışlardır. Kur'ân zikir olduğuna göre, okumak haram değildir. ${ }^{67}$

Dâvud ez-Zahirî, cünüp kimsenin Kur'ân Kerîme dokunmasını caiz görür. Delili, Rasûlullah'ın Herakliyus'a yazdığ bulunuşudur. Gerek Herakliyus gerekse adamları pis (hades) oldukları ve Efendimizin onların dokunacağını bildiği halde mektubuna âyet yazdığını söyleyerek, görüşünü takviye eder. ${ }^{68}$

İbn Hazm, “Hz. Ali rivâyetinin Kur'ân okumamaya delil olamayacağını, çünkü burada yasaklama olmayı $\mathrm{Hz}$ Peygamberin bir halinin haber verildiğini söyler. Üstelik cünüplükten dolayı okumadığına dair bir açıklama yoktur. Hz. Peygamber, ramazan dişında tam bir ay oruç tutmamış, bir vakitte on üç rekâttan fazla namaz kılmamış, ayakta ve yatarken yemek yememiştir. Şimdi biz bunları yaptığımızda haram mı işlemiş oluruz? Cünüp iken okumanın yasak olduğuna dair rivâyetler sahih olmayıp, senetlerinin zayıf olduğunu söylemiştik. Şayet bu konuda, tam bir ayeti veya ayetin bir kısmını okumaya dair açık bir yasaklama olsaydı, şüphesiz bütün bunlar cünüplüyü toptan okumaktan men ederdi." demiştir. ${ }^{69}$

Netice itibariyle hayızlı kadının Kur'ân okumasının hükmü konusunda âlimler görüş ayrılığg içindedir ve bu konuda bir icma yoktur. Kur'ân okumak ve Kur'ân'a

\footnotetext{
${ }^{64}$ Kâsânî, Alâüddîn Ebû Bekr b. Mes'ûd b. Ahmed el-Kâsânî, Kitâbu Bedaii's-Sanai fî̀ Tertibi'ş-Şerâi', (Beyrut: Kütübü'l-İlmiyye, 1974), I, 33; Abdullâh el-Hanefî, Şerhu Sünen-i İbn Mâce, III, 763.

${ }^{65}$ Es-Subkî, Menhelü'l- Azbi'l-Mevrûd, I, 304.

${ }^{66}$ Abdullah el-Hanefi, Şerhu Sünen-i İbn Mâce, III, 763.

${ }^{67}$ Hattâbî, Meâlimü's-Sünen, I, 77; Abdullah el-Hanefi, Şerhu Sünen-i İbn Mâce, III, 755; Es-Subkî, Menhelü'lAzbi'l-Mevrûd, I, 303; Azîmâbâdi, Avnu'l-Ma'bûd, I, 381; Aynî, Umdetü'l-Kâri, III, 406; Mübârekpûrî, Tuhfetül-Ahvezî, I, 408.

${ }^{68}$ Es-Subkî, Menhelü'l- Azbi'l-Mevrûd, I, 304.

${ }^{69}$ İbn Hazm el-Endelüsî, el-Muhallâ bi'l-Âsâr, (Beyrût: Dâru'l-Kütübi'l-İlmiyye, 2010), I, 95.
} 
dokunmak hayırlı işlerdir, teşvik edilmiş, sevap vadedilmiş fiillerdir; bunların bazı hallerde yapılamayacağını söyleyenlerin delil getirmesi (delil ile isbat etmeleri) gerekir.

\section{Abdullah b. Ömer Rivâyeti}

Hayızlı kimsenin Kur'ân okuyamayacağına dair ileri sürülen rivâyetlerden birisi de, Abdullâh b. Ömer'den nakledilmiştir:

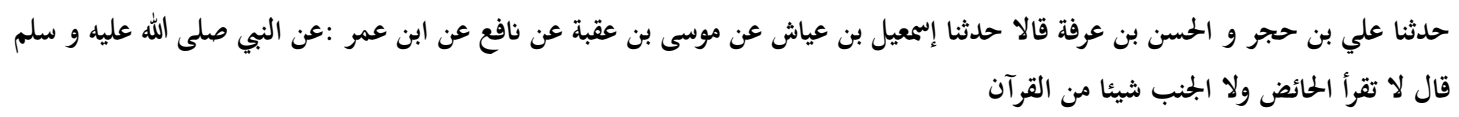

Bize Alî b. Hucr ve Hasân b. Arafe, İsmâîl b. Ayyâşs'tan, o da Mûsâ b. Ukbe'den, o da Nâfi'den, o da İbn Ömer (r.a.)'den rivâyet şöyle rivâyet etmiştir: Rasûlullah (s.a.v.) şöyle buyurmuştur: "Cünüp ve hayızlı olan kimse Kur'ân'dan bir şey okumasın."70 Bu rivâyeti ayrıca İbn Mâce ve Beyhâkî de eserlerine almışlardır. ${ }^{71}$

Rivâyeti eserlerinde nakleden müelliflerle birlikte şema üzerinde şu şekilde göstermek mümkündür:

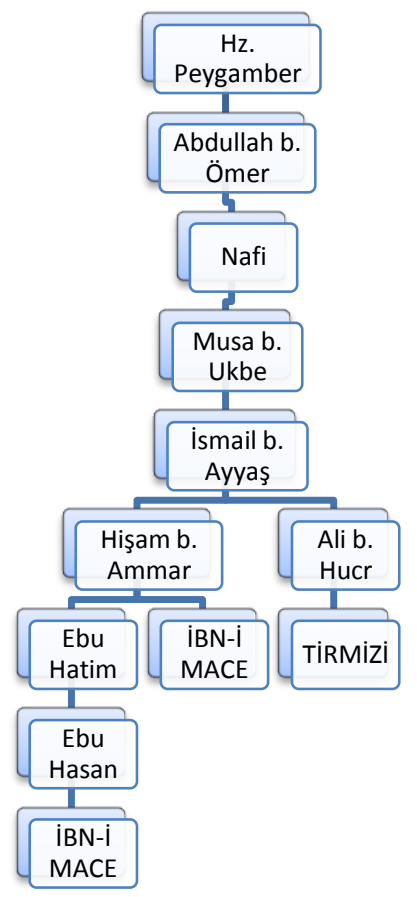

Senet, Hz. Peygamber $\rightarrow$ Abdullâh b. Ömer $\rightarrow$ Nâfi $\rightarrow$ İsmâîl b. Ayyâş'a kadar dört tabakada birer râviden nakledilmiş olup İsmâîl b. Ayyâş'tan üç râvi ile nakledilmiştir. Senette yer alan râvilerin güvenilirlik durumunu şöyledir: TIRMIZÎ

Hz. Peygamber $\rightarrow$ Abdullâh b. Ömer $\rightarrow$ Nâfi $\rightarrow$ İsmâîl b. Ayyâş $\rightarrow$ Alî b. Hucr $\rightarrow$

\footnotetext{
70 Tirmizî, Tahâret, 98.

71 İbn Mâce, Tahâret, 105; Beyhaki, Hayız 5 ( h.n.1522).
} 


\section{Abdullâh b. Ömer (Ö. 73)}

Ebû Abdirrahmân Abdullâh b. Ömer b. el-Hattâb el-Kureşî el-Adevî, ${ }^{72} \mathrm{~Hz}$. Ömer'in oğlu Abdullâh, nübüvvetin üçüncü yılında Mekke'de doğdu. Babasıyla birlikte müslüman oldu, yine onunla birlikte Medine'ye hicret etti. On üç yaşında iken Uhud Savaşı'na katılmak istedi; fakat Hz. Peygamber (s.a.v.)henüz çok genç olduğunu söyleyerek izin vermedi. Bedir Savaşı'na da aynı sebeple kabul edilmediği rivâyet edilir. On beş yaşına girince Peygamber'in izniyle Hendek Savaşı'na katıldı. Bey'atü'rRıdvân'da, Hayber ve Mekke fethi ile Huneyn Gazvesi'nde bulundu. ${ }^{73}$ Hadisleri, başta Hz. Peygamber (s.a.v.)olmak üzere, babası Hz. Ömer, ablası Hafsa, ayrıca Hz. Ebû Bekir, Osman, Âişe, Zeyd b. Sâbit, Bilâl ve Abdullâh b. Mes'ûd gibi ileri gelen sahâbîlerden dinleyip öğrendi. Onun önde gelen hadis talebeleri Abdullah b. Abbas, Câbir b. Abdullah gibi sahâbîlerle Enes b. Sîrîn, Hasan-1 Basrî, Saîd b. Müseyyeb, Nâfi, Mücâhid, Tâvus gibi meşhur tâbiîlerdir. ${ }^{74}$ Kütüb-ü Sitte râvilerinden olup, 2630 hadis ile Ebû Hüreyre'den sonra en çok hadis rivâyet eden yedi sahâbînin (el-müksirûn) ikincisi olmuştur.

\section{Nâfi (Ö. 116)}

Ebû Abdillâh Nâfi b. Hürmüz (Sercis, Kâvus) el-Kureşî el-Adevî el-Medenî, Abdullâh b. Ömer'in âzatlı kölesi, tâbiundandır. ${ }^{75}$ Nâfi, başta İbn Ömer olmak üzere Hz. Âişe, Ebû Saîd el-Hudrî, Ebû Hüreyre, Ümmü Seleme, İbn Ömer'in hanımı Safiyye bint Ebû Ubeyd gibi sahâbîlerden; Hz. Ebû Bekir'in torunları Kâsım b. Muhammed ve Abdullâh b. Muhammed, İbn Ömer'in oğulları Abdullâh, Ubeydullâh, Sâlim ve Zeyd gibi tâbiîlerden hadis rivâyet etti. Kendisinden İbn Şihâb ez-Zührî, Ebû İshak es-Sebiî, Humeyd et-Tavîl, İbn Cüreyc, Abdullâh b. Avn, İbn Ebû Leylâ gibi tâbiîler hadis rivâyet etti. Mâlik b. Enes, Eyyûb es-Sahtiyânî, Yahyâ b. Saîd el-Ensârî, Sâlih b. Keysân, Leys b. Sa'd, Evzâî, İbn İshak, İbn Şübrüme, Nâfî b. Abdurrahmân gibi âlimler onun en tanınmış talebeleridir. Öğrencileri arasında rivâyetleri Kütüb-ü Sitte'de yer alan üç oğlu Abdullâh, Ömer ve Ebû Bekir de vardır. ${ }^{76}$ Nâfî 117 (735) yılında vefat etmiş. Nâfi'in rivâyetlerine Kütüb-ü Sitte başta olmak üzere bütün hadis kitaplarında yer verilmiş, Yahyâ b. Maîn, Ahmed b. Hanbel, Ebü'l-Hasan el-İclî, Nesâî, İbn Sa'd, Onu "sika" olarak değerlendirmiş, "tâbiînin Medine'deki imamlarından biri" kabul edilmiştir. Nevevî de onun "güvenilir bir kişi" olduğunda ulemânın icmâ1 bulunduğunu kaydetmiştir. İmam Mâlik, "Nâfi'in bir rivâyetini duyduğum zaman artık onu bir başkasından duyup duymadığıma önem vermem" demiştir. Buhârî̀ye göre en sahih sened Mâlik - Nâfî - İbn Ömer şeklinde olanıdır. İbn Sa'd üçüncü tabakadan sayarak," sika" olduğunu söylemiştir. ${ }^{77}$

\footnotetext{
72 Mizzî, Tehzîbü'l-Kemâl, XV, 328.

${ }^{73}$ İbn Hacer, Tehzîbü't-Tehzîb, III, 389.

${ }^{74}$ İbn Hacer, Tehzîbü't-Tehzîb, III, 389.

${ }^{75}$ Mizzî, Tehzîbü'l-Kemâl, XXIX, 298; İbn Hacer, Tehzîbü't-Tehzîb, IV, 210.

76 İbn Hacer, Tehzîbü't-Tehzî̉, IV, 210; Mizzî, Tehzîbü'l-Kemâl, XXIX, 299-303.

77 İbn Hacer, Tehzîbü't-Tehzîb, IV, 211; Mizzî, Tehzîbü'l-Kemâl, XXIX, 303.
} 


\section{Mûsâ b. Ukbe (Ö. 141)}

Mûsâ b. Ukbe b. Ebî Ayyâş el-Esedî, Nâfî, Zübeyr, Yahyâ b. Hibbân, Abdullâh b. Dinâr, Zührî gibi âlimlerden rivâyette bulunmuştur. Kendisinden İsmâîl b. İbrâhîm b. Ukbe, Yahyâ b. Saîd, Mâlik, İbn Cüreyc, İbn Mübârek gibi zatlar rivâyet almıştır. İbn Sa'd, O'nu, sika, sebt ve çok hadis rivâyet eden kimse olarak tanıtmıştır. Mâlik, Ebû Bekir b. Heyseme, Iclî, Nesâî de "sika" olduğunu söylemişlerdir. ${ }^{78}$ İbn Hibban Sikat'ında O'nu zikretmiştir. ${ }^{79}$ İbn Hacer, "sika, fakih olduğunu ve meğazi de imam" olduğunu söylemiştir. Kütüb-ü Sitte râvilerinden olup, hicri 141 senesinde vefat etmiştir. ${ }^{80}$

\section{İsmâîl b. Ayyâş (Ö. 106/ 181)}

İsmâîl b. Ayyâş b. Süleym b. El-Ansî el-Humusî, Şurahbil b. Müslim el-Havlânî, Muhammed b. Ziyad, Sevr b. Yezîd'den rivâyet etmiştir. Ondan İbn Mübârek, Mûsâ b. Uyeyne rivâyette bulunmuştur. ${ }^{81}$ İbn Hacer "kendi beldesindekilerden yaptığ 1 rivâyetlerde sadûk, diğer beldelerden yaptığ1 rivâyetlerde muhallıtdır" demiştir. ${ }^{82}$ Ahmed b. Hanbel ve Ebû Zür'a da benzeri bir açıklama yapmıştır. ${ }^{83}$ Yahyâ b. Maîn, "bir sakıncası yoktur" demiştir. İbn Mübârek, "İsmâîl b. Ayyâş ve diğerleri arasında bir tercih yapsam diğerlerini tercih ederim" demiştir. ${ }^{84}$ Hicri 181 senesinde vefat etmiştir..$^{85}$

Hasan b. Arafe (Ö. 147/ 257)

Hasan b. Arafe b. Yezid el-Abdî el-Bağdâdî el-Müezzib. Yahyâ b. Maîn "sika" olduğunu söylemiş, İbn Hibban Sikat'ta onu zikretmiştir. İbn Ebî Hatim "sadûk", Nesâî, Dârekutnî, Abdullah b. Devragî "bir sakınca yoktur" demişlerdir. Hicri 257 yılında vefat etmiştir. ${ }^{86}$

\section{Ali b. Hucr (Ö. 145/ 244)}

Daha önce bilgi verilmiştir. IBNN MÂCE

Hz. Peygamber $\rightarrow$ Abdullâh b. Ömer $\rightarrow$ Nâfi $\rightarrow$ İsmâill b. Ayyâş $\rightarrow$ Hişam b. Ammâr $\rightarrow$

Hz. Peygamber $\rightarrow$ Abdullâh b. Ömer $\rightarrow$ Nâfi $\rightarrow$ Ismâîl b. Ayyâş̧ $\rightarrow$ Hişam b. Ammâr $\rightarrow$ Ebû Hâtim $\rightarrow$ Ebû'l- Hasan $\rightarrow$ IBN MÂCE

\footnotetext{
78 İbn Hacer, Tehzîbü't-Tehzîb, IV, 183-184.

79 İbn Hacer, Tehzîbü't-Tehzîb, IV, 184.

80 İbn Hacer, Et-Takrîb, s. 484.

${ }^{81}$ Ebû Hâtim er-Râzî, el-Cerh ve't-Ta'dîl, II, 191; Buhârî, et-Târihu'l-Kebîr, I, 370.

82 İbn Hacer, Et-Takrîb, s. 48.

${ }^{83}$ Ebû Hâtim er-Râzî, el-Cerh ve't-Ta'dîl, II, 192.

${ }^{84}$ Buhârî, et-Târihu'l-Kebîr, I, 370.

85 İbn Hacer, Et-Takrîb, s. 48.

86 İbn Hacer, Tehzîbü't-Tehzîb, IV, 402; Mizzî, Tehzî̉ü̈'l-Kemâl, VI, 201-205.
} 


\section{Hişâm b. Ammâr (Ö. 153/ 245)}

Hişâm b. Ammâr b. Nusayr es-Sülemî ed-Dimeşkî. İbn Hacer "hatim sadûk ve mugri" olduğunu söylemiş "fakat maruf olup, sika olmadığını" da eklemiştir. ${ }^{87}$ İbrâhîm b. Cüneyd ve Iclî "sika", Merra ve Dârekutnî "sadûk olduğunu söylemiştir. ${ }^{88}$ Merruziyyu, Ahmed b. Hanbel'in "hafif" dediğini nakletmiştir. ${ }^{89}$ Yahyâ b. Maîn, "zeki" olduğunu söylemiştir. "Yaşlandığında hafızasının değiştiği" belirtilmiştir. ${ }^{90}$

\section{Ebû'1-Hasan (Ö. 144)}

Ebû'l-Hasan el-Mervezî es-Sâdî, Şüreyk, İtab b. Beşir, İsmâîl b. Ayyâş'dan rivâyet etmiştir. Kendisinden Müslim b. Haccâc en-Nîsâbûrî rivâyet etmiştir. ${ }^{91}$ İbn Hacer "sika ve hafız" olduğunu söylemiştir. ${ }^{92}$ Hicri 144 senesinde vefat etmiştir. ${ }^{93}$ Buhârî, Müslim, Nesâî ve Tirmizî rivâyetlerini almıştır. ${ }^{94}$

\section{Rivayetlerin Değerlendirilmesi}

Tirmizî, "Bu hadisi, İsmâîl b. Ayyâş ve Mûsâ b. Ukbe haricinde bir senetle bilmiyoruz." demiştir. ${ }^{55}$ Senette İsmâîl b. Ayyâş̧ın bulunmasından dolayı rivâyetin zayıf olduğu bildirilmiştir. ${ }^{96}$

Buhârî, Ahmed b. Hanbel ve İbn Maîn, İsmâîl b. Ayyâş'ın Hicaz ve Irak ehlinden yaptığı nakillerde zayıf olduğunu ve bu hadisi de onlardan aldığını söylemişlerdir. ${ }^{97}$ Ayrıca Ahmed b. Hanbel, bu hadisi babasına sorduğunu onun ise bu hadisin bâtıl olduğunu söylemiştir. ${ }^{98}$ Aynı şekilde Ebû Hâtim babasının, bu hadis için; “ Bu söz İbn Ömer'e ait olduğu için hatalıdır." demiştir.99

Dârekutnî'den gelen senette bulunan Abdü'l-Melik b. Mesleme'nin zayıf bir râvi olduğu, diğer senetteki Ebû Ma'şer'in de zayıf olduğu belirtilmiştir. ${ }^{100}$

Beyhâkî, İsmâîl "münkerü'l-hadis olduğu için hadis sahih değildir" açıklamasını yapmıştır. ${ }^{101}$

İbn Hacer; "merfu olarak İbn Ömer' den nakledilen hadis, rivâyet edildiği bütün senetlere göre zayıftır, şayet sahih olsaydı bu konuda delil olurdu" demiştir. ${ }^{102}$

\footnotetext{
87 İbn Hacer, Et-Takrîb, s. 504.

88 İbn Hacer, Tehzîbü't-Tehzî̀, IV, 276.

89 İbn Hacer, Tehzîbü't-Tehzî̀, IV, 277.

${ }^{90}$ Ebû Hâtim er-Râzî, el-Cerh ve't-Ta'dîl, IX, 66; İbn Hacer, Tehzîbü't-Tehzîb, IV, 277.

${ }^{91}$ Buhârî, et-Târihu'l-Kebîr, VI, 272.

92 İbn Hacer, Et-Takrîb, s. 338.

${ }^{93}$ Buhârî, et-Târihu'l-Kebîr, VI, 272.

94 İbn Hacer, Et-Takrîb, s. 338.

95 Abdullah b. Hanefi, Şerhu Sünen-i İbn Mâce, III, 756; İbn Adiy, el-Kâmilü fì Duâfâ, I, 483; İbn Hacer, Bulû̆̆u'l-Merâm, II, 877.

${ }^{96}$ Abdullah b. Hanefi, Şerhu Sünen-i İbn Mâce, III, 753.

${ }^{97}$ Mübârekpûrî, Tuhfetü'l-Ahvezî, I, 408; Zeyleî, Nasbu'r-Râye, I, 257.

${ }^{98}$ Mübârekpûrî, Tuhfetü'l-Ahvezî, I, 412; İbn Adiy, el-Kâmilü fì Duâfâ, I, 483.

99 İbn Hacer, Bulûğu'l-Meram, II, 887.

100 İbn Hacer, Bulû̆̆u'l-Meram, II, 888.

101 Zeylê̂, Nasbu'r-Râye, I, 256.
} 
Taberânî Evsat'ta, bu rivâyeti zikreder, Ebû Hâtim sebebiyle zayıf olduğunu, Hasan Hâzimî’nin fert kaldığını söylemiştir. ${ }^{103}$ Nevevi ve İbn Kesir, Hâkim b. Hizamı göstererek zayıf bulurlar. ${ }^{104}$

Dârekutnî bu hadisin "zayıf" olduğunu söyler. Metruk olan Muhammed b. Fadl'n bulunduğu bir senetle merfu olarak, Kezzâb olan Yahyâ b. Enise'nin bulunduğu bir senetle mevkuf olarak rivâyet etmiştir. ${ }^{105}$ İbn Hatim İlel adlı eserinde babasından hadisin hatalı olduğunu: "Bu, İbn Ömer'in sözüdür" şeklinde aktarır. Beyhâkî de kuvvetli değil demiştir. ${ }^{106}$

Tirmîzî şârihi, Mübârekpûrî şöyle der: "İbn Mâce de İbn Ömer'in hadisini bu yoldan rivâyet etmiştir. Hadis zayıftır. Çünkü hadis imamları, İsmâîl b. Ayyâş̧ı Şam halkından yaptığı rivâyetlerde sika saymışlar. Fakat Hicâzlılardan yaptığı rivâyetleri zayıf görmüş̧lerdir. Kendisi bu hadisi Hicaz halkından olan Mûsâ b. Ukbe'den rivâyet etmiştir." ${ }^{107}$ Beyhâkî de kuvvetli değil demiştir. ${ }^{108}$

Rivâyeti zayıf bulanlar olduğu gibi aksini söyleyenlerde olmuştur. "Bu hadisin senedi zayıf da sayılsa metni sahihtir. Çünkü bu hususta farklı hadisler bulunur. Bunlar birbirini takviye ettiği için Cumhur, cünüp ve hayız hâlindekilerin Kur'ân okumalarını haram saymıştır." denilmiştir."109

Ahmed b. Hanbel diyor ki: İsmâîl b. Ayyâş̧ "Bakıyye" denilen kimseden daha sağlamdır çünkü "Bakıyye'nin" güvenilir kimselerden hoş olmayan (münker) rivâyetleri vardır. ${ }^{110}$

Bezzâr, bu hadis Mûsâ b. Ukbe'den değil, İbn Abbas'tan biliniyor. Nebi'den hayız konusunda sadece bu senetle gelmiştir. Râzî, babasından İbn Ömer'in sözü olduğunu söylemiş ve Kitabü'l-Ma'rife' de İsmâîl b. Ayyâş̧' in fert kaldığg söylenmiştir. ${ }^{111}$

Beyhâkî de İsmâîl b. Ayyâş'in bu durumu ve teferrüdü sebebiyle İbn Ömer hadisinin muteber olmadığı kanaatindedir. ${ }^{112}$

Neticede İbn Ömer hadisi, illet ve zayıflıktan uzak değildir. Bu hadis, ahkâm konusunda delil olarak muteber görülmemektedir.

\footnotetext{
102 İbn Hacer, Bulü̆ğu'l-Meram, II, 888.

${ }^{103}$ Azîmâbâdi, Avnu'l-Ma'bûd, I, 384; Şevkânî, Neylü'l-Evtar, I, 293.

104 Azîmâbâdi, Avnu'l-Ma'bûd, I, 383.

${ }^{105}$ Mübârekpûrî, Tuhfetü'l-Ahvezî, I, 408; Zeylê̂, Nasbu'r-Râye, I, 257.

${ }^{106}$ Mübârekpûrî, Tuhfetü'l-Ahvezî, I, 412; İbn Adiy, el-Kâmilü fî Duâfâ, I, 483; Zeylê̂, Nasbu'r-Râye, I, 257.

107 İbn Adiy, el-Kâmilü fî Duâfâ, I, 472

${ }^{108}$ Mübârekpûrî, Tuhfetü'l-Ahvezî, I, 412; İbn Adiy, el-Kâmilü fì Duâfâ, I, 483

${ }^{109}$ Mübârekpûrî, Tuhfetü'l-Ahvezî, I, 410

${ }_{110}$ Mübârekpûrî, Tuhfetü'l-Ahvezî, I, 412

111 Abdullah b. Hanefi, Şerhu Sünen-i İbn Mâce, III, 756.

112 Beyhâki, Es-Sünenü'l-Kübrâ, I, 155; Mübârekpûrî, Tuhfetü'l-Ahvezî, I, 412.
} 


\section{Hz. Âişe Rivâyeti}

Müslim, İbn Mâce, Tirmîzî, Ebû Dâvud, Beyhâkî ve Ahmed b. Hanbel, Hz. Âişe'den "Rasûlullâh (s.a.v.), her zaman Allah '1 zikrederdi." haberini talikan rivâyet etmişlerdir: ${ }^{113}$

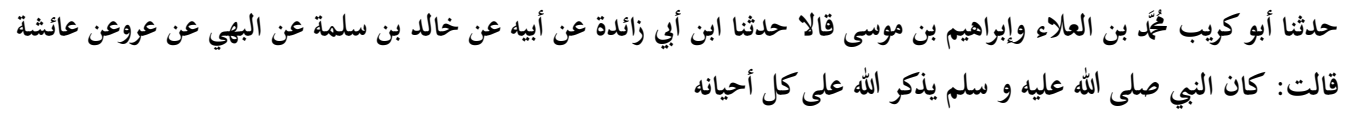

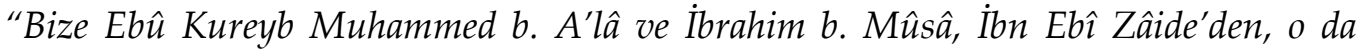
babasından, o da Hâlid b. Seleme'den, o da Behiy'den, o da Urve'den şöyle rivâyet etmişlerdir: Hz. Âişe dedi ki: Bu hadisin isnad şeması şöyledir: "Rasûlullâh (s.a.v.), her zaman Allah ' $\imath$ zikrederdi." 114

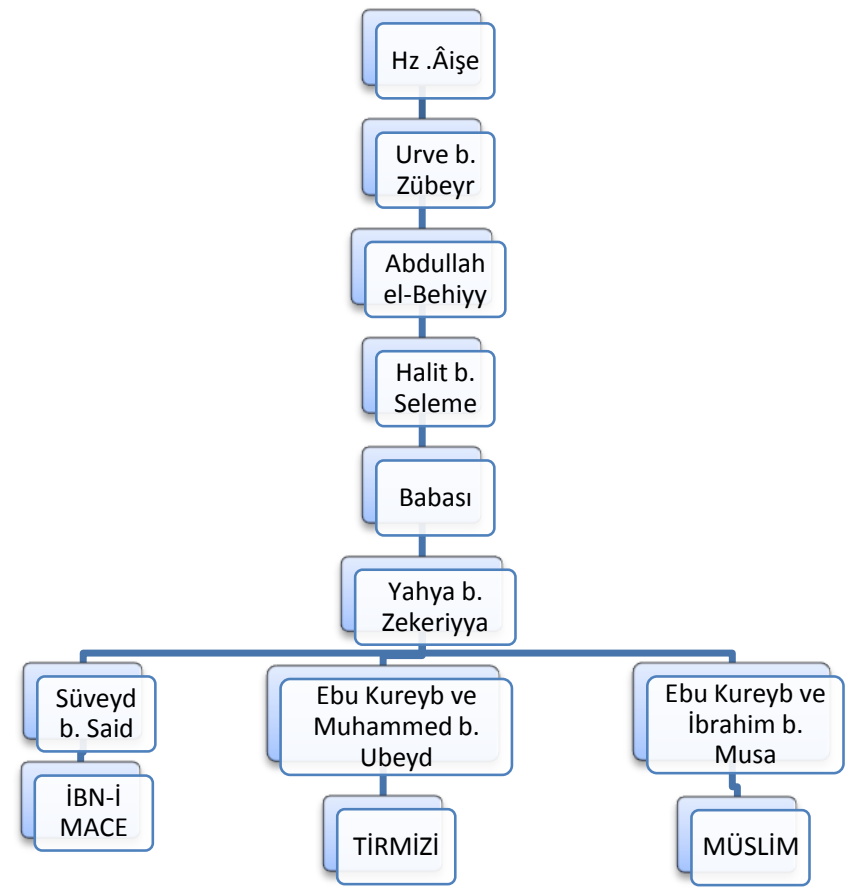

Râviler, Yahyâ b. Zekeriyyâ'dan Hz Âişe'ye kadar teferrüd etmişlerdir. Hadisin râvilerinin durumu ise şöyledir:

Hz. Peygamber $\rightarrow$ Hz. Âş̧e $\rightarrow$ Urve b. Zübeyr $\rightarrow$ Abdullah b. Behiyy $\rightarrow$ Hâlit $b$. Seleme $\rightarrow$ Babası $\rightarrow$ Yahyâ b. Zekeriyyâ $\rightarrow$ Süveyd b. Saîd $\rightarrow$ IBNN MÂCE

Urve b. Zübeyr (Ö. 94)

Urve b. Zübeyr b. Avvâm b. Hüveylid el-Esedî, Hz. Osman'ın hilafetinin başlarında doğdu. Kütüb-ü Sitte âlimlerindendir. Abdullâh b. Ömer b. Hattâb, Abdullâh b. Abbâs, Abdullâh b. Amr b. As gibi pek çok kimseden rivâyet almış; kendisinden de Temîm b. Seleme es-Sülemî, oğlu Abdullâh b. Zübeyr gibi pek çok kişi

113 Müslim, Hayız 30; Ebû Dâvûd, Tahâret 10; Tirmizî, Deavât 9; İbn Mâce, Tahâret 111; Beyhaki, Tahâret h.n.427; Ahmed b. Hanbel, h.n. 26376.

${ }^{114}$ Müslim, Hayız, 30 
rivâyette bulunmuştur. ${ }^{115}$ İbn Sa'd, "Medine ehlinin ikinci tabakasından saymış ve çok rivâyeti olan sika, fakih, me'mun ve sebt" olduğunu söylemiştir. ${ }^{116}$ Iclî, tabiundan "sika bir kimsedir" ve "fitnelere girmemiştir" demiştir. ${ }^{117}$ İbn Uyeyne "Hz. Âişe'ni hadisini bilen üç kişi arasında", Ebû Zinâd "Medine ehlinin dört fakihi" arasında saymıştır. ${ }^{118}$ İbn Hacer "sika, fakih ve meşhur" demiştir. Hicri 94 yılında vefat etmiştir. ${ }^{119}$

\section{Behiy (Ö. ?)}

Abdullah el-Behiy, Mus'ab b. Zübeyr'in kölesi, Künyesi Ebû Muhammed'dir. ${ }^{120}$ Abdullâh b. Ömer b. Hattâb, Abdullâh b. Zübeyr, Ebû Saîd el-Hudrî, Urve b. Zübeyr'den rivâyetleri vardır. ${ }^{121}$ İbn Hacer, sika demiştir. ${ }^{122}$ İbn Hibban Sikat'ta zikretmiş, Buhârî Edeb' de ondan rivâyette bulunmuştur. ${ }^{123}$

\section{Halid b. Seleme (Ö. 132)}

Halid b. Seleme b. As b. Hişâm b. el-Muğîre el- Kureyşî el-Mahzûmî124 için, İbn Hacer "sika" demiştir. Buhârî ve Müslim rivâyetlerini almıştır. ${ }^{125}$ Saîd b. Müseyyeb, Ebû Bürde b. Ebî Mûsâ el-Eşârî gibi kimselerden rivâyet almış, kendisinden Süfyan-1 Sevrî, Şu'be b. Haccâc gibi kimseler rivâyette bulunmuştur. ${ }^{126}$ Buhârî Ali İbn elMedenî'den rivâyetle on kadar hadisi olduğunu söylemiştir. Ahmed $b$. Hanbel, ${ }^{127}$ Yahyâ b. Maîn, Ali İbn el-Medînî, Mevsılî ve Nesâî "sika" olduğunu söylemişlerdir. İbn Hibban "hadisi yazılan bir şeyh" olduğunu bildirmiş, İbn Hatim Sikat'ında zikretmiştir. ${ }^{128}$

\section{Babası (Zekeriyyâ b. Hâlid, Ö. 147)}

İsmi Hâlid b. Meymûn b. Feyrûz, lakabı Ebû Zâide, künyesi ise Ebû Yahyâ'dır. Alî b. El-Medînî "leyse bihi be's", Yahyâ b. Maîn "sâlih", Ahmed b. Hanbel "İbn İshâk'ın seması hariç sika", Ebû Zür'a "Şu'be'den tedlisi çoktur", Nesâî "sika", Ebû Hâtim "leyyinü'l-hadis", 129 İbn Hacer "sadûk"130 demiştir.

\footnotetext{
${ }^{115}$ Mizzî, Tehzî̉ü'l-Kemâl, V, 154; Ebû Hâtim er-Râzî, el-Cerh ve't-Ta'dîl, VI, 520; Buhârî, Et-Târihu'l-Kebîr, VI, 340.

${ }^{116}$ Mizzî, Tehzî̉ü̈l-Kemâl, V, 155.

117 Mizzî, Tehzîbü'l-Kemâl, V, 155.

${ }^{118}$ Ebû Hâtim er-Râzî, el-Cerh ve't-Ta'dîl, VI, 520.

119 İbn Hacer, Et-Takrîb, s. 329.

${ }^{120}$ Mizzî, Tehzîbü'l-Kemâl, IV, 332; İbn Hacer, Et-Takrîb, s. 272.

${ }^{121}$ Mizzî, Tehzîbü'l-Kemâl, IV, 332.

122 İbn Hacer, Et-Takrîb, s. 272.

${ }^{123}$ Mizzî, Tehzîbü'l-Kemâl, IV, 332.

${ }^{124}$ Mizzî, Tehzîbü'l-Kemâl, II, 348; İbn Hacer, Et-Takrîb, s. 168.

125 İbn Hacer, Et-Takrîb, s. 168.

${ }^{126}$ Mizzî, Tehzîbü'l-Kemâl, II, 348; Ebû Hâtim er-Râzî, el-Cerh ve't-Ta'dîl, III, 331.

127 Ebû Hâtim er-Râzî, el-Cerh ve't-Ta'dîl, III, 331.

${ }^{128}$ Mizzî, Tehzî̉bü'l-Kemâl, II, 348.

${ }^{129}$ Mizzî, Tehzîbü'l-Kemâl, IX, 359- 363/ 1992; Ebû Hâtim er-Râzî, el-Cerh ve't-Ta'dîl, III, 593/ 2685.

130 İbn Hacer, Et-Takrîb, s. 156/ 2030.
} 


\section{İbn Ebû Zâide (Yahyâ b. Zekeriyya, Ö. 183)}

Yahyâ b. Zekeriyya b. Ebî Zaide el- Hemdanî Ebû Saîd el-Kûfî, Kütüb-ü Sitte râvilerindendir. ${ }^{131}$ Ebû Yakup İshâk b. İbrâhîm es-Sekafî, Mûsâ el-Cüheni, Nâfî b. Ömer gibi pek çok kimseden rivâyet almıştır. Yine Ahmed b. Hanbel, Ferrâ, Ali b. Medînî gibi çok kimsede ondan rivâyet etmiştir. ${ }^{132}$ İbn Hacer "sika ve mutkîn" demiştir. ${ }^{133}$ Ebû Hâtim "müstegımü'l-hadis, sika ve sadûk"; Nesâ̂i "sika ve sebt"; Iclî, "sika diyerek hadis ve fıkıh ilminin onda birleştiğini", Ali b. Medînî "sika" olduğunu söylemişlerdir. ${ }^{134}$

\section{Süveyd b. Saîd}

Süveyd b. Saîd b. Sehl b. Şehriyar el-Herevî, ${ }^{135}$ pek çok kimseden rivâyette bulunmuş, ondan da çok kişi rivâyet almıştır. ${ }^{136}$ Ebû'l-Kâsım Bağâvî "hafız", Yakub b. Şeybe "sadûk" olduğunu söylemiştir. "Yakub b. Şeybe özellikle a'ma olduktan sonraki rivâyetlerde hafızasının muzdarib olduğunu" da belirtmiştir. Ebû Hâtim, "sadûk ve müdellis" demiştir. Bağdâdî de, "sadûk ama a'ma olduktan sonra telkine açık" olduğunu söylemiştir. ${ }^{137}$

Tirmizî ve Müslim'de yer alan rivâyette bulunan Kureyb'in güvenilirlik durumu şöyledir:

Hz. Peygamber $\rightarrow$ Hz. Âişe $\rightarrow$ Urve b. Zübeyr $\rightarrow$ Abdullah b. Behiyy $\rightarrow$ Hâlit $b$. Seleme $\rightarrow$ Babast $\rightarrow$ Yahyâ b. Zekeriyyâ $\rightarrow$ Ebô Kureyb ve Muhammed $b$. Ubeyd $\rightarrow$ TiRMİZî

\section{Ebû Kureyb ( Ö. 161/ 248)}

Muhammed b. el-A'lâ b. Kureyb el-Hemdânî, künyesi Ebû Küreyb elKûfî'dir. ${ }^{138}$ Binin üzerinde rivâyeti olduğu söylenmiştir. ${ }^{139}$ İbn Hacer "sika ve hafız" demiştir. ${ }^{140}$ İbn Hibban Sikat'ında zikretmiş, İbn Ebî Hatim "sadûk", Nesâî "sika" demişlerdir. ${ }^{141}$ Hicri 148 yılında vefat etmiştir. ${ }^{142}$

\section{Rivayetlerin Değerlendirilmesi}

İbn Mâce rivâyetinin senedi, Zekeriyyâ b. Hâlid'in "müdelles ve leyyinü'lhadis" olmasından dolayı zayıftır. Tirmizî ve Müslim'de yer alan rivâyetlerin zincirinde bulunan râvilerin cerh edilmemiş olması sebebiyle sahihtir.

\footnotetext{
131 İbn Hacer, Et-Takrîb, s. 520; Mizzî, Tehzîbü'l-Kemâl, VIII, 33.

${ }^{132}$ Mizzî, Tehzîbü'l-Kemâl, VIII, 33; Buhârî, et-Târihu'l-Kebîr, VIII, 154; Ebû Hâtim er-Râzî, el-Cerh ve't-Ta'dîl, IX, 178.

${ }^{133}$ İbn Hacer, Et-Takrîb, s. 520.

${ }^{134}$ Mizzî, Tehzîbü'l-Kemâl, VIII, 34.

${ }^{135}$ Mizzî, Tehzî̉bü'l-Kemâl, VIII, 337; İbn Hacer, Et-Takrîb, s. 423.

${ }^{136}$ Mizzî, Tehzîbü'l-Kemâl, III, 337.

${ }^{137}$ Mizzî, Tehzîbü'l-Kemâl, III, 337-338; İbn Hacer, Et-Takrîb, s. 423

138 İbn Hacer, Et-Takrîb, s. 885; Mizzî, Tehzîbü'l-Kemâl, VI, 466.

${ }^{139}$ Mizzî, Tehzîbü'l-Kemâl, VI, 467.

140 İbn Hacer, Et-Takrîb, s. 885.

${ }^{141}$ Mizzî, Tehzîbü'l-Kemâl, VI, 467.

142 Mizzî, Tehzîbü'l-Kemâl, VI, 468.
} 
Şevkânî, bu rivâyetten geneli sınırlandıran bir durum söz konusu olmadıkça, eşyada asıl olanın ibaha olduğu anlaşılır demiştir. ${ }^{143}$

\section{Hayızlı Kadının Kur'ân Okuması İle İlgili Rivâyetlerin Genel Değerlendirilmesi}

Yapılan senet tenkidi neticesinde, hayızlı kadının Kur'ân okuyamayacağı konusunda tek delil olarak bulunan "Abdullâh b. Ömer Rivâyetinin", zayıf olduğu sonucuna ulaşılmıştır. Hayızlı bir kadının Kur'an okumasının haram olduğu şeklinde bir hüküm verilirken, sahih hadislerin gösterilmesi gerekir. "Ali b. Ebî Tâlib Rivâyeti" ise hasen olup, cünüp kimsenin okuyamayacağı konusunda delildir. Hayızlı kadın ile cünübün kıyas edilmesi konusunun gözden geçirilmesi gerekir. "Hz. Âişe Rivâyeti” de sahih olup, Rasulullah'ın her halde Allah'ı zikrettiğini bizlere haber vermektedir. Buradaki zikir kelimesinin manasının herhangi bir karine olmadan daraltılması da yine üzerinde durulması gereken bir konudur. ${ }^{144}$

\section{B. Kadınların Özel Hallerinde Mushaf'a Dokunması ile İlgili Rivâyetin Tahlili ve Değerlendirilmesi}

Hayızlı kadınların Mushaf'a dokunamayacaklarına delil olarak gösterilen tek rivâyet Amr b. Hazm'a aittir.

\section{Amr b. Hazm'in Mektubu}

Dârimî, Nesâî, İbn Hibban, Dârekutnî ve Beyhâkî tarafindan tahriç edilen rivâyette, ${ }^{145}$ Hz. Peygamber (s.a.v.) Ensar'dan Amr b. Hazm'1 (ö.50/670) Necran halkına nıuallim ve zekât memuru olarak göndermiş ve ona zekât, diyet ve diğer bazı hükümleri ihtiva eden bir de mektup vermişti. Bu mektuptaki hükümlerden birisi de şuydu: "Kur'ân'a ancak temiz olan (tâhir) dokunur."

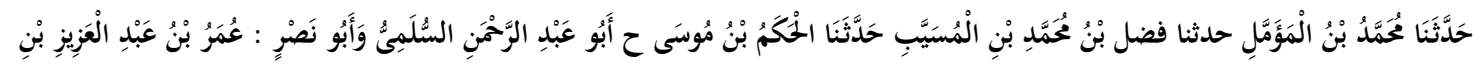

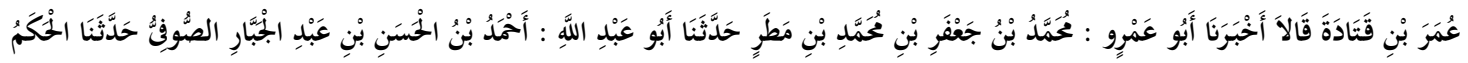

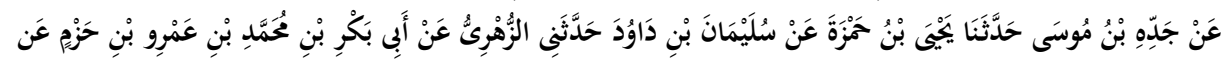

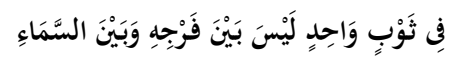

"Bize Ebû Abdi'r-Rahmân Muhammed b. el-Hüseyni es-Sülemî, o da Muhammed b. Müemmel'den, o da Fadl b. Muhammed $b$. Müseyyeb'den, o da Hakem b. Mûsâ'dan rivayet etti: ح Bize Ebu Abdi'r-Rahmân es-Sülemî ve Ebû Nasr ( Ömer b. Abdi'l-Aziz b. Ömer b. Katâde)

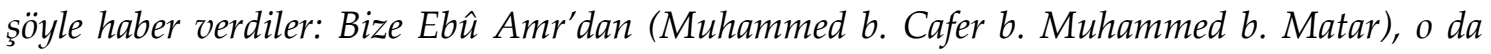
Ahmed b. el-Hüseyin b. Abdi'l-Cebbâr es-Sûfi'den, o da Hakem b. Mûsâ'dan, o da Yahyâ b. Hamza'dan, o da Süleymân b. Dâvud'dan, o da Zührî'den, o da Ebû Bekr b. Muhammed b. Hazm'dan, o da babasindan, o da dedesinden şöyle rivayet etti: Kur'ân'a ancak temiz olanlar

\footnotetext{
${ }^{143}$ Şevkâni, Neylü'l-Evtâr, I, 322.

144 Bkz. Mustafa Hocaoğlu, "Hayızlı-Cünüb Kimseler Ve Kur'an Tilaveti”, Dokuz Eylül Üniversitesi İlahiyat Fakültesi Dergisi, 28 (İzmir 2008), 11-30.

${ }^{145}$ Beyhâki, Sünenü'l-Kübrâ, II, 6; Dârimî, Talak 3; Nesâî, Kasame 46, 47; Hâkim, Müstedrek, I, 395-397
} 
dokunabilirler. Temlikten önce talâk yoktur. Ödeme yapılıncaya kadar hürriyet yoktur. Tek ve küçük örtü içinde namaz kılınmaz. İki ucu omuzlar üzerine atılabilecek genişlikte olan örtü bundan müstesnadır. Secdede avret mahalli yukarı doğru açılacak şekilde tek örtüye sarılıp bürünerek ve başının saçın toplayıp ensede bağlayarak namaz kılınmaz."

Mektubun tam metninin bulunduğu Beyhâkî'nin Sünen'inde, ${ }^{146}$ rivâyetin pek çok konuda muhtasar olarak bablarda tekrar edildiğini görüyoruz. Yine İbn Hibban, Hâkim, Dârekutnî, Nesâî de muhtasar olarak kitaplarına almışlardır. ${ }^{147}$

Nesâ̂i, Amr b. Hazm mektubunun diyet ve zekâtla ilgili kısımlarını tahriç etmekle birlikte, "Kur'ân'a ancak temiz olan (tâhir) dokunur" ibaresine yer vermemiştir. ${ }^{148}$

Hadisin tam metninin bulunduğu Beyhâkî'deki senetle beraber, hadisin isnâd şeması şöyledir:

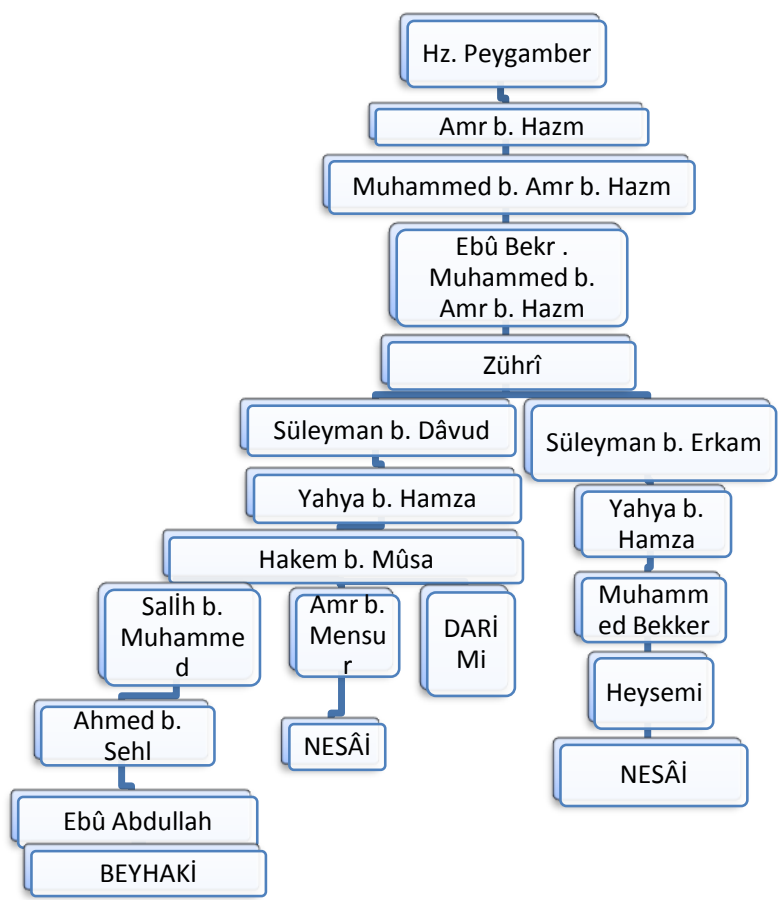

Hz. Peygamber'den sonra, dört tabakada birer râvi tarafından nakledilip, Zühri' den sonra iki râviyle nakli devam eden rivâyet ferd/garibtir.

\section{Amr b. Hazm (Ö. 50/ 670)}

Amr b. Hazm b. Zeyd b. Levzân el-Ensârî el- Medînî, ${ }^{149}$ Ebû Muammed el Hazreci150 "meşhur bir sahabi" idi. Onun Hendek harbinden itibaren savaşlara katılmasına izin verildiği ${ }^{151}$ ve on yedi yaşlarında iken Necran halkına muallim ve

\footnotetext{
${ }^{146}$ Beyhakî, Sünenü'l- Kübrâ, 7357 nolu hadis, (Beyrût: Dâru'l-Fikr, 2010), V, 484

147 İbn Hacer, Bulû̆̆g'l-Meram, II, 788

148 Nesâî, Kasame, 46.

149 Buhârî, et-Târihu'l-Kebîr, VI, 305.

${ }^{150}$ Mizzî, Tehzîbü'l-Kemâl, XXI, 585.

${ }^{151}$ İbn Hacer, Et-Takrîb, s. 357.
} 
zekât memuru olarak gönderildiği nakledilir. ${ }^{152}$ Bazı kaynaklar, Amr b. Hazm'ın Hz. Ömer'in hilafeti döneminde takriben 50/670 senesinde vefat ettiğini bildirmişlerdir. ${ }^{153}$ Ebû Dâvud, Merâsil de; Nesâî ve İbn Mâce, Sünen kitaplarında rivâyetine yer vermişlerdir. ${ }^{154}$

\section{Muhammed b. Amr b. Hazm (Ö. 63/683)}

Amr b. Hazm'ın oğlu Muhammed el-Ensârî, künyesi Ebû Abdülmelik elMeden $\hat{1}^{155}$ tabiîdir. Ömer b. Hattâb, Amr b. As ve babası Amr b. Hazm'dan rivâyette bulunmuştur. Nesâî "sika", Vakidî "rivâyeti az, sika bir kimsedir" demiştir. ${ }^{156}$ İbn Sa'd "onun az hadis nakleden güvenilir râvilerden" olduğunu söylemiştir. İbn Hibban da onu "sika râviler" arasında tanıtmıştır. ${ }^{157}$ Onun Kütüb-ü Sitte'de sadece Nesâî'de biricik hadisi bulunmaktadır ki, bu da konumuzla ilgili rivâyettir. Hicri 63 yılında vefat etmiştir. ${ }^{158}$

\section{Ebû Bekr b. Muhammed b. Amr b. Hazm (Ö. 120/738)}

Amr b. Hazm'ın torunu Ebû Bekr, tabiinden olup Kütüb-ü Sitte'de hadisleri bulunan bir râvidir. İbn Hacer, İbn Maîn ve İbn Hiraş; Ebû Bekr için "sika ve âbid" demişlerdir. İbn Hibban Sikât'ında zikretmiştir. ${ }^{159}$ Hicri 120 yılında vefat etmiştir. ${ }^{160}$

\section{Zührî (Ö. 52/124)}

Muhammed b. Müslim b. Ubeydullâh b. Abdillâh b. Şihâb, âlimlerin önde gelenlerinden Hicaz ve Şam âlimidir. ${ }^{161}$ Pek çok kimseden rivâyet almış, ondan da çok kime rivâyet etmiştir. Buhârî, bin kadar rivâyetinin olduğunu söylemiştir. ${ }^{162}$ İbn Sa'd "sika, hadisleri çok, rivâyetlerde cami ve fakihtir" demiştir. ${ }^{163}$ Ebû Zinâd şöyle der: " Biz helalleri ve haramları yazardık. Zührî ise duyduğu her şeyi yazardı. İhtiyaç olduğunda bunları insanlara bildirirdi." ${ }^{164}$ Hicri 120 yılında vefat etmiştir. ${ }^{165}$

Halife Ömer b. Abdilaziz tarafından Medine kadısı ve idarecisi (vali) olarak görevlendirilmiştir. ${ }^{166} \mathrm{Bu}$ arada halife Ömer $\mathrm{b}$. Abdülaziz 'in ondan sahabe ya da tabiinden duyduğu hadis ya da hükümleri yazıya geçirmesini istediği nakledilir. İşte dedesi Amr b. Hazm'ın mektubunun gündeme gelmesi de bu tarihlere rastlar. Nitekim Ömer b. Abdilaziz'in teşviki üzerine İmam Zührî Medine'ye gelerek Ebû Bekr'den

\footnotetext{
152 Mizzî, Tehzîbü'l-Kemâl, XXI, 585.

153 İbn Hacer, Et-Takrîb, s. 357; Buhârî, et-Târihu'l-Kebîr, VI, 305.

${ }^{154}$ Mizzî, Tehzîbü'l-Kemâl, XXI, 585; İbn Hacer, Et-Takrîb, s. 357.

155 İbn Hacer, Et-Takrîb, s. 433; Mizzî, Tehzîbü'l-Kemâl, XXVI, 202.

${ }^{156}$ Mizzî, Tehzîbü'l-Kemâl, XXVI, 203.

${ }^{157}$ Mizzî, Tehzî̉ü'l-Kemâl, XXVI, 203.

158 İbn Hacer, Et-Takrîb, s. 433.

159 İbn Hacer, Tehzîbü't-Tehzî̀, IV, 495.

160 İbn Hacer, Et-Takrîb, s. 551; İbn Hacer, Tehzîbü't-Tehzîb, IV, 495.

161 İbn Hacer, Tehzîbü't-Tehzî̀, III, 696.

162 Bk. İbn Hacer, Tehzîbü't-Tehzîb, III, 696-697; Mizzî, Tehzîbü'l-Kemâl, XXVI, 420-431.

${ }^{163}$ Mizzî, Tehzîbü'l-Kemâl, VI, 432.

164 İbn Hacer, Tehzîbü't-Tehzîb, III, 697; Mizzî, Tehzîbü'l-Kemâl, XXVI, 433.

165 İbn Hacer, Tehzîbü't-Tehzî̀, III, 698.

${ }^{166}$ Buhârî, et-Târihu'l-Kebîr, IX, 10.
} 
dedesine ait olan bu mektubu kendisine nakletmesini ister. Ebû Bekr de ona bu mektubu ve Amra bint Abdirrahman, Kâsım b. Muhammed gibi râvilerden işittiği hadisleri aktarır. ${ }^{167} \mathrm{Bu}$ faaliyetler, aynı zamanda resmi tedvin döneminin ilk örneklerindendir.

Amr b. Hazm, takriben 50/670 senesinde vefat etmiştir. Oğlu Muhammed ise 63/683'te -elli üç yaşında- vefat etmiştir. Vefat tarihi 120/738 olan Ebû Bekr ise dedesi Amr'la görüşmemiştir. Hatta babası Muhammed'in vefatı esnasında Ebû Bekr'in on yaşlarında olduğu tahmin edilmektedir. Mektubun rivâyet sahasına çıkarıldığı tarih ise, Ömer b. Abdilaziz'in (101-720) hilafeti dönemine tekabül etmektedir. Buna göre, Ebû Bekr b. Muhammed'in mektubun aslını tamamen şifahi olarak alması ve nakletmesi, tarihi yönden oldukça uzak bir ihtimaldir. Onun mektubu daha sonraları kayda geçmeye çalıştığı düşünülürse, arada büyük bir zaman aşımının bulunması sebebiyle, dedesi vasitasıyla Hz. Peygamber'e nisbet ettiği metinlerde şaibeli hususların vukuu kuvvetle muhtemeldir.

Zührî'nin vicade yoluyla naklettiği söylenen bu mektubu Ebû Dâvud, "Merasil"de müsned olarak rivâyet etmiş ve "sahih değildir" demiştir. ${ }^{168}$

\section{Süleymân b. Erkâm}

Süleyman b. Erkâm el-Basrî, künyesi Ebû Muâzdır. ${ }^{169}$ Kendisinden rivâyet aldığı kimseler içinde Zührî, Yahyâ b. Ebî Bekir, Hasan Basrî bulunmaktadır. Kendisinden Sevrî, Haccac el-Havlânî rivâyet etmiştir. ${ }^{170}$ İbn Hacer "zayıf" demiştir. ${ }^{171}$ Ahmed b. Hanbel "ondan hadis rivâyet edilmez", Yahyâ b. Maîn "leyse bişey", Buhârî "onu terk edin", Ebû Zür'a "metrûku'l-hadis, daifu'l-hadis", Cürcani "sâkıt" demiştir. ${ }^{172}$

Nesâî'de yer alan bu rivâyetin senedi, her tabakada birer râvi tarafından nakledildiği içn ferd/gariptir. Süleymân b. Erkâm'ın münekkitler tarafından ağır bir şekilde cerh edilmesi sebebiyle bu rivâyetin zayıf olduğu kanaatine ulaşmış bulunmaktayız. Dârimî'de yer alan ve konumuzu ilgilendiren senedin râvilerinin tenkidi ise şöyledir:

\section{Süleymân b. Dâvud}

Süleymân b. Dâvud el Havlânî, Ebû Dâvud ed-Dımeşkî. Eyyûb b. Nâfî, Zührî'den rivâyetleri vardır. ${ }^{173}$ İbn Hacer "sadûk"174 İbn Hibbân "sika", Ali b. Medînî "münkeru'l-hadis, zayıf", Yahyâ b. Maîn "zayıf (leyse bişey) demiştir. ${ }^{175}$

\footnotetext{
167 İbn Hacer, Tehzîbü't-Tehzîb, IV, 495.

168 İbn Hacer, Bulûğu'l-Meram, II, 788; Zeyleî, Nasbu'r-Râye, I, 258.

${ }^{169}$ Buhârî, et-Târihu'l-Kebîr, IV, 22.

${ }^{170}$ Mizzî, Tehzîbü'l-Kemâl, III, 261; Ebû Hâtim er-Râzî, el-Cerh ve't-Ta'dîl, IV, 97.

${ }^{171}$ İbn Hacer, Et-Takrîb, s. 189.

${ }^{172}$ Mizzî, Tehzîbü'l-Kemâl, III, 262.

${ }^{173}$ Mizzî, Tehzîbü'l-Kemâl, III, 276.

174 İbn Hacer, Et-Takrîb, s. 191.

${ }^{175}$ Mizzî, Tehzîbü'l-Kemâl, III, 262.
} 
Zührî'den bu hadisi nakleden "Süleymân" hakkında bazı çelişkili haberler bulunmaktadır. Zira Dârimî, Nesâî, İbn Hibban ve Beyhâkî, bu rivâyetin Süleymân b. Dâvud el-Havlânî adındaki güvenilir râvi kanalıyla gelen sahih bir hadis olduğunu savunmuş ${ }^{176}$ ve İbn Hibban, Süleymân b. Dâvud'un sika, güvenilir bir râvi olduğunu söylemiştir. ${ }^{177}$ İbn Hazm ve Abdü'l-Hak İşbîlî; Süleymân b. Erkâm'dan nakledilmesi sebebiyle bu rivâyetin zayıf ve illetli olduğuna dikkat çekmişlerdir. ${ }^{178} \mathrm{Kimi}$ âlimler ise bu rivâyetin her iki râvi kanalıyla gelmesinin mümkün olduğunu; bu itibarla vecihlerinden birisinin sahih, diğerinin illetli olduğunu belirtmişlerdir. ${ }^{179}$ İbn Hacer; “Muttasıl senetler illetlidir. Bu konuya musannıflar dikkat çekmişler ve Süleymân b. Erkâm bulunması sebebiyle bu senedin zayıf olduğunu söylemişledir. Çünkü Süleymân gerçekten zayıf biridir." demiştir. ${ }^{180}$

Öte yandan bu râvinin adıyla ilgili üçüncü bir isim tartışmasını gündeme getiren İbn Hazm, bu kişinin Süleymân b. Dâvud el-Yemâmî (ya da el-Yemânî) adındaki "metruk bir râvi" olduğunu ve bu sebeple hadisin delil olarak kullanılamayacağını ileri sürmüştür. ${ }^{181}$

\section{Yahyâ b. Hamza (Ö. 183)}

Yahyâ b. Hamza Vakıd el-Hadramî, künyesi Ebû Abdurrahmân ed-Dımeşk'tir. İbn Hacer "sika, kaderci denilmiştir", 182 Ebû Dâvud "sika, kaderci", Abdullâh b. Muhammed "zararı yoktur (la be'se bih)", Muhammed b. Sa'd "hadislerinin çoğu sâlih", Ebû Hâtim "sadûk", Yahyâ b. Maîn "sika, kaderci", Yakub b. Şeybe "sika meşhur", Iclî "sika" demiştir. ${ }^{183}$

\section{Hakem b. Mûsâ (Ö. 232)}

Hakem b. Mûsâ b. Ebî Züheyr el-Bağdâdî, künyesi Ebû Salih el-Gantarî' dir. İbn Hacer "sadûk", ${ }^{184}$ Ahmed b. Hanbel "leyse bihi be's", Ebû Heyseme, Yahyâ b. Maîn, Iclî “sika", Ebû Hâtim "sadûk" demiştir. ${ }^{185}$

Dârimî'de yer alan bu rivâyetin senedi, her tabakada birer râvi tarafından nakledildiği için ferd/gariptir. Süleymân b. Dâvud'un "münkeru'l-hadis, zayıf" olarak cerh edilmiştir. Yahyâ b. Hamza ve Hakem b. Mûsâ için "sadûk, hadisi sâlih" denilerek sika mertebesine çıkamadıkları ifade edilmiştir. Bu sebeplerle rivâyetin zayıf olduğunu söylemek durumundayı.

\footnotetext{
176 İbn Hacer'in de bu görüşü benimsediği anlaşılmaktadır. İbn Hacer, Bulŭğu'l-Meram, II, 877; Zeylê̂, Nasbu'r-Râye, I, 259.

177ỉbn Hacer, Bulû̆̆u'l-Meram, II, 877; Zeylê̂, Nasbu'r-Râye, I, 259.

178 İbn Hacer, Bulû̆ğu'l-Meram, II, 878; Bk. İbn Adiy Cürcânî, Kâmilü fi Duâfâ, IV, 228

179 Nesâî 'nin bu rivayeti hem Süleyman b. Dâvûd, hem de Süleymân b. Erkâm tarikıyla ayrı ayrı tahriç etmiş bulunduğunu yukarıdaki şemada da görmekteyiz.

180 İbn Hacer, Bulûğ '́l-Merâm, II, 878.

${ }^{181}$ Mübarekpûrî, Tuhfetu'l-Ahvezî, I, 455.

182 İbn Hacer, Et-Takrîb, s. 1052.

${ }^{183}$ Mizzî, Tehzîbü'l-Kemâl, VIII, 28.

184 İbn Hacer, Et-Takrîb, s. 264.

${ }^{185}$ Mizzî, Tehzîbü'l-Kemâl, II, 250.
} 
Nesâî, Süleymân b. Erkâm İçin "metruk" demiştir. Dârekutnî, bu hadisi "Ğarâibü Mâlik"de rivâyet etmiş ve "Kur'ân'a ancak temiz olanlar dokunabilir" ibaresinin dedesinden değil, Mâlik'ten sahih olduğunu söylemiştir. Abdürrezzak, Musannef te mürsel olarak rivâyet etmiştir. Dârekutnî ve Beyhâkî de mürsel demişlerdir. ${ }^{186}$

\section{Kadınların Özel Hallerinde Mushafa Dokunması ile İlgili Rivâyetin Değerlendirilmesi}

Netice itibariyle "hayızlıların Kur'ân'a dokunamayacağına" delil olarak gösterilen bu rivâyetler sahih değildir. Bu görüşü ispatlamak için sahih hadislerin gösterilmesine ihtiyaç vardır. ${ }^{187}$

\section{SONUÇ}

İslâm Dini'nin iki ana kaynağı hiç şüphesiz Kur'an ve Sünnet'tir. Dolayısıyla dinin anlaşılması üzerine yapılan çalışma ve gayretler Kur'an ve Sünnet eksenli olma yönünde gelişme kaydetmiştir. Hz. Peygamber (s.a.v)'in sünneti ise Kur'an'ın beyânı olma özelliğine sahiptir. Bu nedenle sünnet, tarih boyunca Kur'ân'ı anlama çabalarında en temel unsur olma özelliğini korumuştur. Hadis-i şerifler de Hz. Peygamber (s.a.v)'in sünnetinin metin halinde günümüze kadar ulaşmış formudur. Dolayısıyla hadisleri anlamak ve yorumlamak, Hz. Peygamber (s.a.v)'in hayatını ve sünnetini ve bu münasebetle de Kur'an'ı anlamaktır. Bu düşünceden hareketle hadis araştırmalarında, Hz. Peygamber (s.a.v)'den gelen rivayetlerin anlaşılması konusunda pek çok çalışma yapılmıştır. Bu araştırmalar içerisinde, İslam düşünce tarihi boyunca tartışmalı konuları ihtiva eden hadis metinlerinin müstakil olarak incelenmesi de büyük önem arz etmektedir.

Din eğitiminin yaygınlaşmasıyla beraber, kadınların özel halleri ile ilgili farklı görüşlerin ortaya çıtığı görülmektedir. Hayızlı kadının Kur'ân okuyup okuyamayacağı, mescide girip giremeyeceği gibi konular, günlük hayatı çok yakından ilgilendirmektedir.

Çalışmamızda, kadınların özel hallerini ilgilendiren rivâyetler, hadis tenkidi kriterleri içerisinde incelenmiştir. Bu rivâyetlerden şu sonuçlara ulaşılmıştır:

Hayızlı kadının Kur'ân okuyamayacağı konusunda tek delil olarak bulunan “Abdullah b. Ömer (Cünüp ve hayızlı olan kimse Kur'ân'dan bir şey okumasın) rivâyetinin" zayıf olduğu sonucuna ulaşılmıştır. İbn Ömer hadisi, illet ve zayıflıktan uzak olmadığı için ahkâm konusunda delil olarak muteber görülmemektedir. "Ali b. Ebî Talib rivâyeti" ise hasen olup, cünüp kimsenin okuyamayacağı konusunda delildir.

\footnotetext{
186 Zeylaî, Nasbu'r-Râye, I, 259-260.

187 Bkz. Hasan Elik, "Mushaf'a Abdestsiz Dokunulup Dokunulamayacağı Problemi”, İlmi Araştırmalar Dergisi, 6 (Nisan 1998), 48-78; Arif Ulu "Âdet Halindeki Kadının Orucuyla ilgili Hadislerin Tenkidi", Atatürk Üniversitesi İlahiyat Fakültesi Dergisi, 28 (Erzurum 2012), 1-50; Ali Akpınar, "Mushafa Abdestsiz Dokunma Meselesi", Cumhuriyet Üniversitesi İlahiyat Fakültesi Dergisi, 5 (Sivas 2001), 81-109; Kadir Paksoy, "Kur'ân'a Abdestli Dokunmakla İlgili Rivâyetlerin Tahlili", Harran Üniversitesi İlahiyat Fakültesi Dergisi, 5 (Şanlıurfa 1999): 330-378.
} 
Cünüplük hali iradidir. Hayız hali ise irade dışı ve uzun süren bir durumdur. Bu münasebetle, hayızlı kadın ile cünübün kıyas edilerek aynı hükümlere tâbi tutulmaları konusunun fâkihler tarafından tekrar gözden geçirilmesi gerekir.

“Hayılıların Kuran'a dokunamayacağına" delil olarak gösterilen, “Amr b. Hazm'ın mektubu rivâyeti", zayıftır.

Bu çalışma neticesinde, "kadınlar hayızlı iken Kur'ân okuyamaz" ve "Mushaf'a dokunamaz" şeklinde verilen hükümlerin zayıf rivâyetlere dayandığı tespit edilmiştir.

“Hayızlı kadınlar Kur'ân okuyamaz"görüşünde olan fakihler; kıyas, sahâbî kavli, örf gibi deliller ile hükme ulaşmışlardır. Bu konuda yer alan hadisleri zayıf olsa da görüşlerine dayanak olarak kullanmışlardır. Ancak kadınların ibadet hayatını doğrudan etkileyen bu mühim mevzularda, hükme mesned olacak rivayetlerin sahih olması gerekmektedir.

Ayrıca fakihlerin delil olarak ileri sürdükleri bazı hadislerin birbirini nakzettiği görülmektedir. Mesela bazı imamların cünüb olan kimsenin iki ayeti veya bir ayetin yarısını okuyabilir fetvaları ile Hz. Ali“eden nakledilen "Cünüb olan kimse, Kur'ân'dan bir harf dahi okuyamaz" hadisini kabul etmedikleri anlaşılmaktadır. Bazı şarihler de söz konusu hadisleri mezhebleri doğrultusunda şerh etmeye çalışmış olsalar da İbn Hacer ve İbn Battal gibi Buhârî Şarihleri, cünüb ve hayızlı kimselerin Kur'an okuyabileceklerine hükmetmişlerdir.

Fakihlerin görüşleri mukayeseli olarak incelendiğinde, konuya farklı yaklaştıkları görülmektedir. Yani bu konuda oluşmuş bir icma yoktur. Fıkıhta icmâ bağlayıcıdır, ama çoğunluğun görüşü bağlayıcı değildir. Meşhur dört mezhepte de bazen biri, diğerlerinin tamamina (bu mânada cumhura) muhalif olduğu halde mensupları -çoğunluğun ictihadını değil- tek kalmış olan mezhebin ictihadını uygulamaktadırlar. Hayızlı iken Kur'ân okumaya ve dokunmaya izin veren görüşlerin de olduğu unutulmamalıdır. Bu ihtilaflardan, kadınların özel hallerinde ibadet ile ilgili olan konuların tartışmaya açık olduğu anlaşılmaktadır.

Kadınlar, özel hallerinde Kur'an okumaya zorlanmıyor; ama onlar farklı (caiz diyen) ictihada uyar da bunları yaparlarsa yine kimsenin onları engellemeye veya kınamaya hakları olamaz.

\section{KAYNAKÇA}

Ahmed B. H. (1963). Kitâbu'l -illel ve Marifeti'r-Rical, haz. İsmail Cerrahoğlu, Talat Koçyiğit, Ankara: Ankara İlahiyat Yayınları.

Akpınar, A. (2001). Mushafa Abdestsiz Dokunma Meselesi, Cumhuriyet Üniversitesi İlahiyat Fakültesi Dergisi, 5: 81-109.

Aynî, Ebû Muhammed (Ebü's-Senâ) (2005). Bedrüddîn Mahmûd b. Ahmed b. Mûsâ b. Ahmed el Aynî, Umdetü'l-Kâri fi Şerhi Sahîhi'l-Buhârî, Beyrût: Dâru'l-Kitâbi'l-İlmiyye.

Azîmâbâdî, Ebû Abdirrahman Şer'îf (2005). Avnu'l-Ma'bûd Şerh-i Sünen-i Ebî Dâvûd, Beyrût: Dâru İbn Hazm.

Beyhâkî, Ahmed b. Hüseyin (2010). Sünenü'l-Kübrâ, Beyrût: Dâru'l-Fikr. 
Buhârî, Ebû Abdullâh Muhammed b. İsmâîl b. İbrâhîm el-Cưfî el-Buhârî, el-Câmiu's-Sahîh, Riyâd: Beytu'l-Efkâr 1998. et-Târihu'l-Kebîr, Beyrut: Dâru'l-Kütübü'l-İlmiyye, 2008.

Dalgın, Nihat, Gündemdeki Tartışmalı Dini Meseleler, İstanbul: Ensar Neşriyat, 2014.

Dârekutnî, Ali b. Ömer, ed-Duâfâ ve'l-Metrûkîn, tahkik: Abdullah b. Abdulkâdir, Mektebetü'lMaârif, Riyâd 1984.

Dârimî, Ebû Abdullâh b. Abdu'r-Rahmân b. Fadl b. Behram, Sünenü'd-Dârimî, haz. Hasan Selim Esed, Riyad: Dâru'1-Muğanni 2000.

Ebû Dâvud, Süleymân b. Eşâsî el-Ezdî es-Sicistânî, es-Sünen, tahkik: Muhammed Avvâme, Beyrût: Müessesetü'r-Rayyân 2004.

Ebû Hâtim, İbn Ebî Hâtim Muhammed b. İdrîs et-Temîmi el-Hanzalî, El-Cerh ve't-Ta'dil, tahkik: Mustafa Abdülkâdir Atâ, Beyrût: Dâru'1-Kütübi'l-İlmiyye 2010.

Elik, Hasan, "Mushaf'a Abdestsiz Dokunulup Dokunulamayacağı Problemi”, Kur'ân Mesajı İmi Araştırmalar Dergisi, 6 (Nisan 1998): 48-78.

El-Mâverdî, Ebü'l-Hasen Alî b. Muhammed b. Habîb el-Basrî el-Mâverdî, el-Hâvi'l-Kebir fî Fıkhi Mezhebi'ş-Şafî̀, Beyrut: Daru'l-Kütübi'l-İmiyye, 1994.

Hattâbi, Ebû Süleymân Hamed b. Muhammed b. İbrâhîm el-Hattâbî el-Büstî, Meâlimü's-Sünen, haz. Muhammed Râgıb et-Tabbâh, Halep: Matbaâtü'l-İlmiyye 1932.

Hocaoğlu, Mustafa, “Hayızl1-Cünüb Kimseler ve Kur'an Tilaveti”, Dokuz Eylül Üniversitesi Ilahiyat Fakültesi Dergisi, 28 (İzmir 2008): s.11-30.

Iclî, Ahmed b. Abdillâh, Ma'rifetü's-Sikât, tahkik: Abdü'l-Âlim el-Bustî, Medine: Mektebetü'dDâr 1985.

İbn Adiy, el-Kâmilü fi'd-Duafâi'r-Ricâ'l, tahkik: Abdü'l-Fettâh Ebû Sünne, Beyrut: Dâru'lKütübi'l-İlmiyye 2011.

İbn Hâcer El-Askalâni, Ebû'l-Fazl Şihâbüddîn Ahmed b. Alî b. Muhammed, Fethu'l-Bâri Şerhu Sahih-İ Buhârî, Riyâd: Dâru's-Selâm 2000.

--------, Bulü̆̆u'l-Merâm min Edilleti'l-Ahkâm, Riyâd: Mektebetü'r-Rüşd 2006.

--------, Et-Takrîbü't-Tehzîb, Riyâd: Dâru'l-Âsîme tarihsiz.

--------,Tehzîbu't-Tehzîb, Beyrût: Dâru'1-Kütübi'1-İlmiyye 2004.

İbn Hazm El-Endelüsî, el-Muhallâ bi'l-Âsâr, Beyrût: Dâru'l-Kütübi'l-İlmiyye, 2010.

İbn Hibban, Ebû Hâtim Muhammed b. Hibbân b. Ahmed el-Büstî, Kitâbü's-Sikât, Hindistan: Müessesetü Kütübi's-Sekafiyye tarihsiz.

İbn Kudâme, Ebû Muhammed Muvaffakuddîn Abdullah b. Ahmed b. Muhammed b. Kudâme el-Cemmâîlî el-Makdisî, el-Muğnî, Riyad: Mektebetü'r-Riyâdi'l- Hadîse, 1971.

İbn Mâce, Ebû Abdillâh Muhammed b. Yezîd Mâce el-Kazvînî, Sünen-ü İbn Mâce, Riyâd: Mektebetü'1-Maârif tarihsiz.

İbn Receb El-Hanbelî, Ebü'1-Ferec Zeynüddîn Abdurrahmân b. Ahmed b. Abdirrahmân Receb el-Bağdâdî ed-Dımaşki, Fethu'l-Bâri alâ Sahîhi'l-Buhârî, Medine: Mektebü'1-Ğurebâi'lEseriyye 1996. 
--------, Şerhu 'Íleli't-Tirmizî, Ürdün: Mektebetu'l-Menar 1987.

Kandehlevî, Muhammed Zekeriyyâ, Kevkebü'd-Düreri alâ Câmi'it-Tirmîzî, Hindistan: Nedvetü'lUlemâ 1975.

Kâsânî, Alâüddîn Ebû Bekr b. Mes'ûd b. Ahmed el-Kâsânî, Kitâbu Bedaii's-Sanai fì Tertibi'ş-Şerâi', Beyrut: Kütübü'l-İlmiyye, 1974.

Mizzî, Ahmed b. Abdullah b. Salih, Tehzîbü'l-Kemâl, Beyrût: Müessesetü'l-Risâle, 2010.

Mübârekpûrî, Ebü'l-Ulâ Muhammed Abdurrahmân b. Abdirrahîm el-Mübârekpûrî, Tuhfetü'lAhvezî bi Şerhi Câmii't-Tirmîzî, haz. Abdurrahman Muhammed Osman, Misır: Dâru'lFikr 1968.

Müslim, Ebü'l-Hüseyn Müslim b. el-Haccâc b. Müslim el-Kuşeyrî, Sahîhu Müslim, Riyâd: Beytu Efkâri Düveliyye 1998.

Nesâî, Ebû Abdirrahmân Ahmed b. Şuayb b. Alî en-Nesâî, Sünenü'l-Kübrâ, haz. Abdullah b.Abdu'l-Muhsin, Beyrût: Müessesetü'r-Risâle 2001.

Nevevî, Ebû Zekeriyyâ Muhyiddîn Yahyâ İbn-i Şeref, Sahîh-i Müslim bi Şerhi'n-Nevevî, Mısır: Matbaâtü'l-Misriyye 1929.

Paksoy, Kadir, "Kur'ân'a Abdestli Dokunmakla İlgili Rivâyetlerin Tahlili”, Harran Üniversitesi İlahiyat Fakültesi Dergisi, 5 (Şanlıurfa 1999): 330-378.

Subkî, Mahmûd Muhammed Hattâb es-Sübkî, Menhelü'l-Azbi'l-Mevrûd, haz. Emin Mahmud Hattab, Riyâd: Mektebetü'l- İslamiyye 1974.

Şeyh Nizam, Fetâvâ-i Hindiyye, Beyrût: Dâru'l-Fikr, 2009.

Şevkânî, Ebû Abdullah Muhammed b. Ali b. Muhammed el-Havlâni, Neylü'l-Evtâr min Esrâri Münteka'l-Ahbâr, haz. Enver el-Bâz, Mısır: Dâru'l-Vefa, 2008.

Tirmîzî, Muhammed b. Îsâ, Câmiu'l-Kebîr, tahkik: Beşşâr Avvâme, Beyrût: Dâru'l-Ğarbi'l-İslâmî 1996.

Ukaylî, Ebû Ca'fer Muhammed b. Mûsâ b. Hammâd, Kitâbü'l- Duafâi'l-Kebîr, Beyrut: Dâru'lKütübü'l-İlmiyye 1984.

Ulu, Arif, "Âdet Halindeki Kadının Orucuyla ilgili Hadislerin Tenkidi", Atatürk Üniversitesi İlahiyat Fakültesi Dergisi, 28 (Erzurum 2012): 1-50.

Yavuz, Yunus Vehbi, “Hayız”, TDV İslâm Ansiklopedisi (DİA), İstanbul: Türkiye Diyanet Vakfı 1998.

Zeyleî, Ebû Muhammed Cemâlüddîn Abdullāh b. Yûsuf b. Muhammed ez-Zeyleî, Nasbu'r-Râye li Ehâdîsi'l-Hidâye, haz. Muhammed Avvâme, Beyrût: Dâru'l-Kütübi'l-i̇lmiyye 1997. 